\title{
Anthropometric and dietary indicators applied in population-based surveys: a systematic review
}

Indicadores antropométricos e dietéticos utilizados em estudos de base populacional: uma revisão sistemática

Indicadores antropométricos y dietéticos utilizados en estudios poblacionales: una revisión sistemática

Natália Louise de Araújo Cabral ORCID: https://orcid.org/0000-0002-9166-1917 Federal Institute of Education, Science and Technology of Sertão Pernambucano, Brazil

E-mail: natalia.louise@ifsertao-pe.edu.br

Nila Patrícia Freire Pequeno

ORCID: https://orcid.org/0000-0003-1279-2554

Federal University of Rio Grande do Norte, Brazil E-mail: nilapfp@hotmail.com

David Franciole de Oliveira Silva

ORCID: https://orcid.org/0000-0003-0940-1356

Federal University of Rio Grande do Norte, Brazil E-mail: davfranci@hotmail.com

Sandra Patrícia Crispim

ORCID: https://orcid.org/0000-0002-2257-9899 Federal University of Paraná, Brazil E-mail: sandracrispim@gmail.com

Dirce Maria Lobo Marchioni

ORCID: https://orcid.org/0000-0002-6810-5779 University of São Paulo, Brazil E-mail: marchioni@usp.br

Severina Carla Vieira Cunha Lima

ORCID: https://orcid.org/0000-0001-8268-1986 Federal University of Rio Grande do Norte, Brazil

E-mail: scvclima@gmail.com

Clélia de Oliveira Lyra

ORCID: https://orcid.org/0000-0002-1474-3812 Federal University of Rio Grande do Norte, Brazil E-mail: clelia_lyra@yahoo.com.br

\begin{abstract}
Aim: To identify population-based health and nutrition surveys, conducted with adults and the elderly, and performed in the Americas, Europe, and Oceania, to investigate the more common anthropometric and food consumption methods used, their applicability, and their limitations. Methods: Electronic databases (LILACS, PubMed, and SCOPUS) were systematically searched for studies published between 1997 and 2017 in Portuguese, English, or Spanish. 48 studies (45.8\% carried out in the Americas) met the eligibility criteria and were included in the review. The data were analyzed in 2018. Results: The methodological quality of most of the studies (64.4\%) was classified as moderate, according to the Agency for Healthcare Research and Quality checklist for cross-sectional studies and the Newcastle-Ottawa scale for cohort studies. 35.4\% of the articles evaluated only food consumption, $29.2 \%$ just anthropometry, while $35.4 \%$ evaluated food consumption and anthropometric measurements. The most used food survey methods were food record (31\% of studies) and the 24-hour dietary recall (22\% of studies). Body mass index (BMI) was the most used indicator for anthropometric nutritional status assessment. Although most of the studies used the World Health Organization classification criteria, these studies did not adopt the different cut-off points for BMI classification for adults and the elderly. Conclusion: BMI and methods that record current consumption, such as the food record and the 24-hour dietary recall, were the main methods of assessing nutritional status, taking into consideration the easy application, low cost, and good reproducibility. Systematic Review Registration: PROSPEROCRD42017071392.
\end{abstract}

Keywords: Nutrition surveys; Population surveys; Food consumption; Anthropometry; Systematic review. 


\begin{abstract}
Resumo
Objetivo: Identificar pesquisas de saúde e nutrição de base populacional, com adultos e idosos, e realizadas nas Américas, Europa e Oceania, para investigar os métodos antropométricos e de consumo alimentar mais utilizados, sua aplicabilidade e limitações. Metodologia: Bases de dados eletrônicas (LILACS, PubMed e SCOPUS) foram sistematicamente pesquisadas em busca de estudos publicados entre 1997 e 2017 em português, inglês ou espanhol. 48 estudos (45.8\% realizados nas Américas) atenderam os critérios de elegibilidade e foram incluídos na revisão. Os dados foram analisados em 2018. Resultados: A qualidade metodológica da maioria dos estudos (64,4\%) foi classificada como moderada, conforme o checklist da Agency for Healthcare Research and Quality para estudos transversais e a escala Newcastle-Ottawa para estudos de coorte. $35.4 \%$ dos artigos avaliaram apenas o consumo alimentar, 29.2\% apenas a antropometria, enquanto $35.4 \%$ avaliaram o consumo alimentar e as medidas antropométricas. Os métodos de consumo alimentar mais utilizados foram o registro alimentar (31\% dos estudos) e o recordatório de $24 \mathrm{~h}$ ( $22 \%$ dos estudos). O índice de massa corporal (IMC) foi o indicador mais utilizado para avaliação antropométrica. Embora a maioria dos estudos tenha utilizado os critérios da Organização Mundial da Saúde, estes não adotaram pontos de corte diferentes para classificar o IMC de adultos e idosos. Conclusão: o IMC e os métodos que registram o consumo atual, como o registro alimentar e o recordatório de $24 \mathrm{~h}$, foram os principais métodos de avaliação do estado nutricional, levando-se em consideração a fácil aplicação, baixo custo e boa reprodutibilidade. Registro de revisão sistemática: PROSPEROCRD42017071392.
\end{abstract}

Palavras-chave: Inquéritos nutricionais, Inquéritos populacionais, Consumo alimentar, Antropometria, Revisão sistemática.

\title{
Resumen
}

Objetivo: Identificar encuestas poblacionales de salud y nutrición, realizadas con adultos y ancianos, y realizadas en las Américas, Europa y Oceanía, para investigar los métodos antropométricos y de consumo de alimentos más utilizados, su aplicabilidad y limitaciones. Metodología: Se realizaron búsquedas sistemáticas en bases de datos electrónicas (LILACS, PubMed y SCOPUS) de estudios publicados entre 1997 y 2017 en portugués, inglés o español. 48 estudios (45.8\% realizados en las Américas) cumplieron con los criterios de elegibilidad y se incluyeron en la revisión. Los datos se analizaron en 2018. Resultados: La calidad metodológica de la mayoría de los estudios (64,4\%) se clasificó como moderada, según la lista de verificación de la Agency for Healthcare Research and Quality para los estudios transversales y la escala de Newcastle-Ottawa para los estudios de cohortes. $35.4 \%$ de los artículos solo evaluó el consumo de alimentos, el $29.2 \%$ solo la antropometría, mientras que el $35.4 \%$ evaluó el consumo de alimentos y las medidas antropométricas. Los métodos de consumo de alimentos más utilizados fueron el registro de alimentos (31\% de los estudios) y el recuerdo de 24 horas (22\% de los estudios). El índice de masa corporal (IMC) fue el indicador más utilizado para la evaluación antropométrica del estado nutricional. Aunque la mayoría de los estudios utilizaron los criterios de clasificación de la Organización Mundial de la Salud, estos estudios no adoptaron diferentes puntos de corte para clasificar el IMC de adultos y ancianos. Conclusión: El IMC y los métodos que registran el consumo actual, como los registros de alimentos y el retiro de alimentos de 24 horas, fueron los principales métodos para evaluar el estado nutricional, teniendo en cuenta su fácil aplicación, bajo costo y buena reproducibilidad. Registro de revisión sistemática: PROSPEROCRD42017071392.

Palabras clave: Encuestas nutricionales; Estudios poblacionales; Consumo alimentario; Antropometría; Revisión sistemática.

\section{Introduction}

The demographic, epidemiological and nutritional changes, occurring worldwide, in recent decades have resulted in significant transformations in morbidity and mortality patterns. In this context, population-based health and nutrition surveys have been applied since the 1960s in developed countries, and are currently experiencing an increase in many developing countries, with the objective of monitoring the health status of populations (Viacava, 2002).

The health and nutrition surveys are essential for health surveillance, in addition to enabling the analysis of inequalities. These surveys provide updated and reliable information that may contribute to the development of health programs and services in the most diverse population groups, serving as important instruments for public policies planning and evaluation (Barros, 2008; Malta, Célia, \& Szwarcwald, 2017; Malta et al, 2008; Sperandio \& Priore, 2017).

In most cases, population-based surveys are part of cohort or cross-sectional surveys, and aggregate a set of sociodemographic characteristics, variables of lifestyle factors and health outcomes, data collection methodology, and periodicity. A periodic update on survey is important for the consolidation of the information collected, which becomes the 
basis for population references, enabling surveillance of chronic noncommunicable diseases (NCDs) and their causes (Szwarcwald et al., 2014).

Health-related behaviours, which have a greater impact on the demand for health services and on the quality of life of people, or that address risk factors for NCDs are the most studied, owing to their influence on population morbidity and mortality. Thus, surveys have gained considerable importance in the assessment of lifestyle factors such as smoking, alcohol consumption, physical activity, sedentary behaviour, diet quality, overweight/obesity, hypertension, diabetes, violence, accidents, and mental disorders (Barros, 2008; Malta, Célia, \& Szwarcwald, 2017).

The use of surveys including anthropometric indicators and food consumption are relevant in the assessment and monitoring of the dietary, nutritional, and health status conditions of the population (Sperandio \& Priore, 2017), data widely described in the literature (Willet, 2013). In the case of dietary patterns, monitoring is an important mechanism to identify changes or trends in consumption and to understand the relationship between dietary exposure and varied health outcomes, as well as providing information relating to food, along with considering the nutritional interactions involved. The pattern of food consumption can also be used as an indirect indicator of nutritional status (Silva, Lyra, \& Lima, 2016).

Some of the more common dietary surveys used in the identification of dietary patterns are the food record or diary, direct weighing of food, 24-hour dietary recall (R24h), dietary history, and the food frequency questionnaire (FFQ). There is no 'gold standard' method because each has its advantages and limitations. Therefore, the choice of method will depend on the characteristics of the population assessed and the objectives of the study (Fisberg, Marchioni, \& Colucci, 2009; Shim, Oh, \& Kim, 2014; Silva et al., 2016; Sperandio \& Priore, 2017; Willet, 2013).

For anthropometric assessments, a direct method of assessment of nutritional status, population surveys have frequently utilized measurements of weight and height, owing to the ease of assessment and low cost of the equipment used, as well as the simplicity of the method, the use of non-invasive techniques, the reduced time to validate measures, the ease of training of personnel for data collection, and the reliability, when measured and evaluated properly by trained professionals (Duarte, 2007; Guedes, 2007; Sperandio \& Priore, 2017).

Another advantage attributed to anthropometry is the easy comparison of measurements obtained with population and international standards used in the diagnosis of nutritional status, according to sex and age range, or the comparison between measurements, for the verification of changes in the dimensions and body composition of individuals (Nacif, 2007). On the other hand, the limitations of this method are related to their validation and accuracy, because it depends not only on the adequate training of field staff, but also on the use of calibrated equipment and standardization of the measures (Sperandio \& Priore, 2017).

The reliability in the application of the method, the standardization of measures, and the possibility of international comparisons influence the reliability of the data and the reproducibility of the studies. Thus, this study aimed to perform a systematic review of population-based health and nutrition surveys, conducted with adults and the elderly in the Americas, Europe, and Oceania, to identify which anthropometric and food consumption methods were most frequently used, along with their applicability and limitations. These continents were selected because the dietary habits of Western populations are similar, in that there is a growing inclusion in the diet of foods high in calories, fat, and refined sugars, while they have low consumption of fruits and vegetables and fiber, in contrast to the diets in Eastern (Arab and Asian) and African countries.

\section{Methodology}

\section{Design}

This was a systematic review of original studies, prepared according to the recommendations of Preferred Reporting Items for Systematic Reviews and Meta-Analyses (PRISMA) 2009 (Moher et al., 2015), designed with the objective of guiding 
the dissemination of systematic reviews and meta-analyses in health field. The review was registered in the international prospective register of systematic reviews (PROSPERO) under the number 2017: CRD42017071392.

\section{Search strategy}

A virtual search was performed in the LILACS, PubMed, and Scopus databases, for original articles published between 1997 and 2017. The following search strategy was used in PubMed: ('Health Surveys' OR 'Nutrition Surveys' OR 'Diet Surveys') AND ('Nutritional Status' OR 'Nutrition Assessment'OR'Nutrition, Public Health') AND (adult OR adults OR aged OR elderly) AND ('cross-sectional studies' OR surveys) AND ('nationwide survey' OR 'national nutrition monitoring' OR 'national survey'). In the Scopus database, the key words used were: TITLE-ABS-KEY ('Health Surveys' OR 'Nutrition Surveys' OR 'Diet Surveys') AND TITLE-ABS-KEY ('Nutritional Status' OR 'Nutrition Assessment' OR 'Nutrition, Public Health') AND TITLE-ABS-KEY (adult OR adults OR aged OR elderly) AND TITLE-ABS-KEY ('crosssectional studies' OR surveys) AND TITLE-ABS-KEY ('nationwide survey' OR 'national nutrition monitoring' OR 'national survey'). In LILACS the following combination of terms was used: (Inquérito OR pesquisa) AND (saúde OR nutrição OR dieta OR 'consumoalimentar' OR 'estadonutricional' OR antropometria OR “composiçãocorporal”) AND (nacional OR populacional). The searches were performed from April to July 2017 and confined to articles published between January 1997 and July 2017, in Portuguese, English, or Spanish. Data were analyzed in 2018.

\section{Inclusion and exclusion criteria}

The papers were considered eligible when they met the following inclusion criteria: 1) Observational studies; 2) Performed in adult and/or elderly populations; (3) Surveys carried out over the last 20 years (1997 to 2017); 4) Conducted in Europe, Americas, and/or Oceania; and 5) Available in Portuguese, English, or Spanish. Systematic reviews, meta-analyses and studies involving pregnant women were excluded from the study.

\section{Synthesis and comparison of results}

Initially, two evaluators independently reviewed the titles and abstracts to verify if those met the proposed eligibility criteria. Then, the complete texts of the papers were read. Subsequently, each evaluator completed, independently, a data mining spreadsheet, including, in addition to the evaluation of the methodological quality, the following items: 1) Characteristics of the studies: authors, year of publication, place of study (country and continent), and the evaluation of the methodological quality score. The population of each study was described according to the number and age of participants. 2) Characteristics of surveys: name, year, variables, method, frequency of application of the nutritional survey, and evaluation criteria of the anthropometric nutritional status and the respective cut-off points. Discrepancies in the evaluation were resolved through discussion between the evaluators, and, in case of doubt, a third reviewer was consulted.

\section{Evaluation of the methodological quality of the studies}

The methodological quality of the selected papers was evaluated and scored according to the recommendations of the Newcastle-Ottawa quality assessment scale (NOS) for cohort studies, and the Agency for Healthcare Research and Quality (AHRQ) checklist for cross-sectional studies. The NOS evaluation consists of eight questions, which include items such as: selection of participants, comparability between the subjects and verification of exposure. The papers are scored as 'Good', 'Adequate', or 'Poor', in accordance with the score received on each item of the scale (items are identified with one or no stars). The sum of these items (stars) classifies the article. The AHRQ consists of 11 items, with the options 'Yes', 'No', or 'Unclear'. A score ' 0 ' is attributed to items evaluated with 'No' or 'Unclear', and score ' 1 ' for those evaluated with 'Yes'(Shi, 
Ying, Du, \& Shen, 2017).

To better present the results, the score evaluated by NOS was converted into quality categories, based on the document from the AHRQ (AHRQ. Agency for Healthcare Research and Quality). Based on these results, three categories for evaluation were established: 0-3, 4-7, and 8-11, indicating low, moderate, and high quality, respectively.

Criteria for evaluation of methodological quality of primary studies

The following indicators of anthropometric evaluation and assessment of habitual consumption were considered as standard in the assessment of the methodological quality of the primary studies: 1) BMI: two or more measurements; 2) food surveys: at least two applications (for 24-hour dietary recall and food record), as recommended in the literature (Hoffmann et al., 2002). To check the quality of the anthropometric data collected, we investigated if the papers mentioned calibration of anthropometric instruments and training of the interviewers.

\section{Results}

The search recovered 615 documents. In addition, another 22 articles were added by manual search. 53 documents of the 637 were duplicated and for this reason were excluded, resulting in 584 abstracts. After reading the title and abstract, 253 articles were excluded. Thereafter, after considering the inclusion and exclusion criteria of 331 articles read in full, 48 studies were included in the review (Figure 1).

Figure 1. Flowchart of study selection.

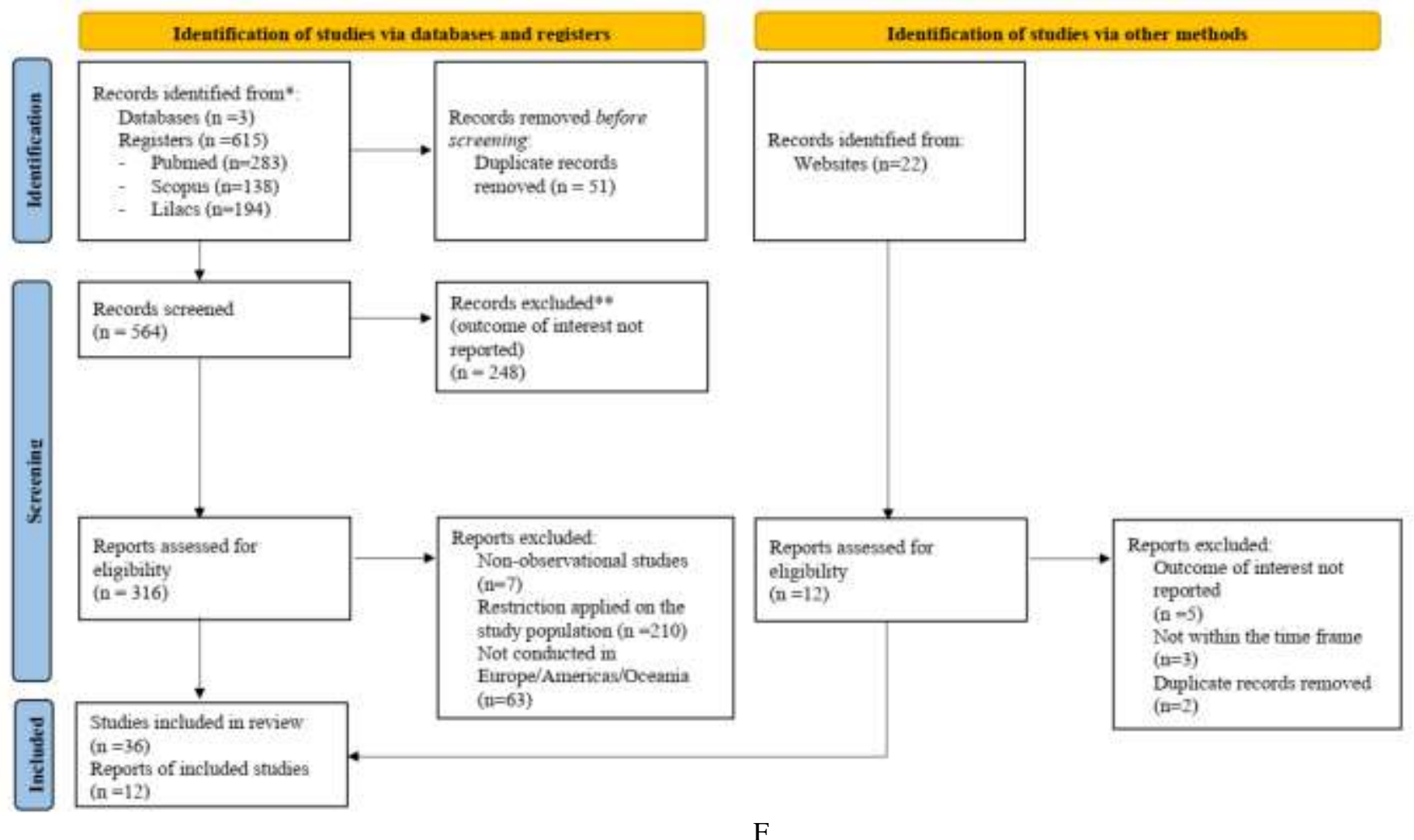

Source: Authors.

\section{Methodological quality and characteristics of the studies}

Given the criteria for the classification of methodological quality, for the 48 studies included, 31 were classified as moderate quality $(64.6 \%)$ and 17 as high quality $(35.4 \%)$. Regarding the continent where the study was implemented, $45.8 \%$ 
$(n=22)$ were conducted in the Americas (Acosta, 2013; Acosta et al, 2005; Barquera et al., 2009, 2010; Barr, DiFrancesco, \& Fulgoni, 2016; Bays, Chapman, \& Grandy, 2007; Bezerra \& Sichieri, 2011; Ferreira \& Benicio, 2015; Gray-Donald, JacobsStarkey, \& Johnson-Down, 2000; Guendelman et al., 2013; Kant, Graubard, 2015; Kordas et al., 2012; Melano-Carranza, Lasses Ojeda, \& Ávila-Funes, 2008; Meller et al., 2014; Pavão, 2013; Pereira, Duffey, Sichieri, 2014; Pisabarro et al., 2009; Ponce et al., 2013; Sichieri et al., 2015; Tande, Magel, \& Strand, 2009; Velasquez-Melendez et al., 2015), 47.9\% (n=23) in Europe (Alkerwi et al., 2015; Alkerwi et al., 2015a; Beltrán-de-Miguel, Estévez-Santiago, \& Olmedilla-Alonso, 2015; Bjermo et al., 2013; Cooper et al., 2014; Gazan et al., 2016; Gose et al., 2016; Kruizenga et al., 2003; Marcenes et al., 2003; Meier et al., 2010; Nissensohn et al., 2016, 2017; Pot et al., 2015; Pot et al, 2014; Prynne et al. , 2009; Ruiz et al., 2016; Tressou et al., 2016; Vernay et al., 2009; Whitton et al., 2011), and 6.3\% (n=3) in Oceania(Bell, Edwards, \& Grieger, 2015; Lei et al, 2016; Mohr et al., 2007). In relation to countries, Brazil contributed 14.6\% ( $n=7)$ of the publications (Bezerra \& Sichieri, 2011; Ferreira \& Benicio, 2015; Meller et al., 2014; Pavão, 2013; Pereira, Duffey, Sichieri, 2014; Sichieri et al., 2015; VelasquezMelendez et al., 2015); Spain (Beltrán-de-Miguel et al., 2015; Nissensohn et al., 2016, 2017; Ruiz et al., 2015, 2016), the United States (Bays et al., 2007; Cifelli et al, 2016; Guendelman et al., 2013; Kant, Graubard, 2015; Tande et al., 2009), and England (Cooper et al., 2014; Pot et al., 2015; Pot et al., 2014; Prynne et al., 2009; Whitton et al, 2011) contributed five each; Mexico (Barquera et al., 2009, 2010; Melano-Carranza et al., 2008; Ponce et al., 2013) four; Australia (Bell et al., 2015; Lei et al., 2016; Mohr et al., 2007) and France(Gazan et al., 2016; Tressou et al., 2016; Vernay et al., 2009) three; Canada (Barr et al., 2016; Gray-Donald et al., 2000), Colombia (Acosta, 2013; Kordas et al., 2012), Luxembourg (Alkerwi et al., 2015; Alkerwi et al., 2015a) and Netherlands (Kruizenga et al, 2003; Sluik et al, 2014) two; Germany (Gose et al., 2016), Cuba (Acosta et al, 2005), the United Kingdom (Marcenes et al., 2003), Sweden (Bjermo et al, 2013), Switzerland (Meier et al., 2010), and Uruguay (Pisabarro et al., 2009) contributed one study each (Figure 2).

The studied population ranged from 273 (Bjermo et al, 2013) to 215,354 (Bays et al., 2007) individuals. In relation to the nutrition variables analysed, 35.4\% $(\mathrm{n}=17)$ of the papers evaluated food consumption and anthropometry, 35.4\% $(\mathrm{n}=17)$ only food consumption, and $29.2 \%(n=14)$ only anthropometry (Figure 2). 
Figure 2. Characteristics of studies.

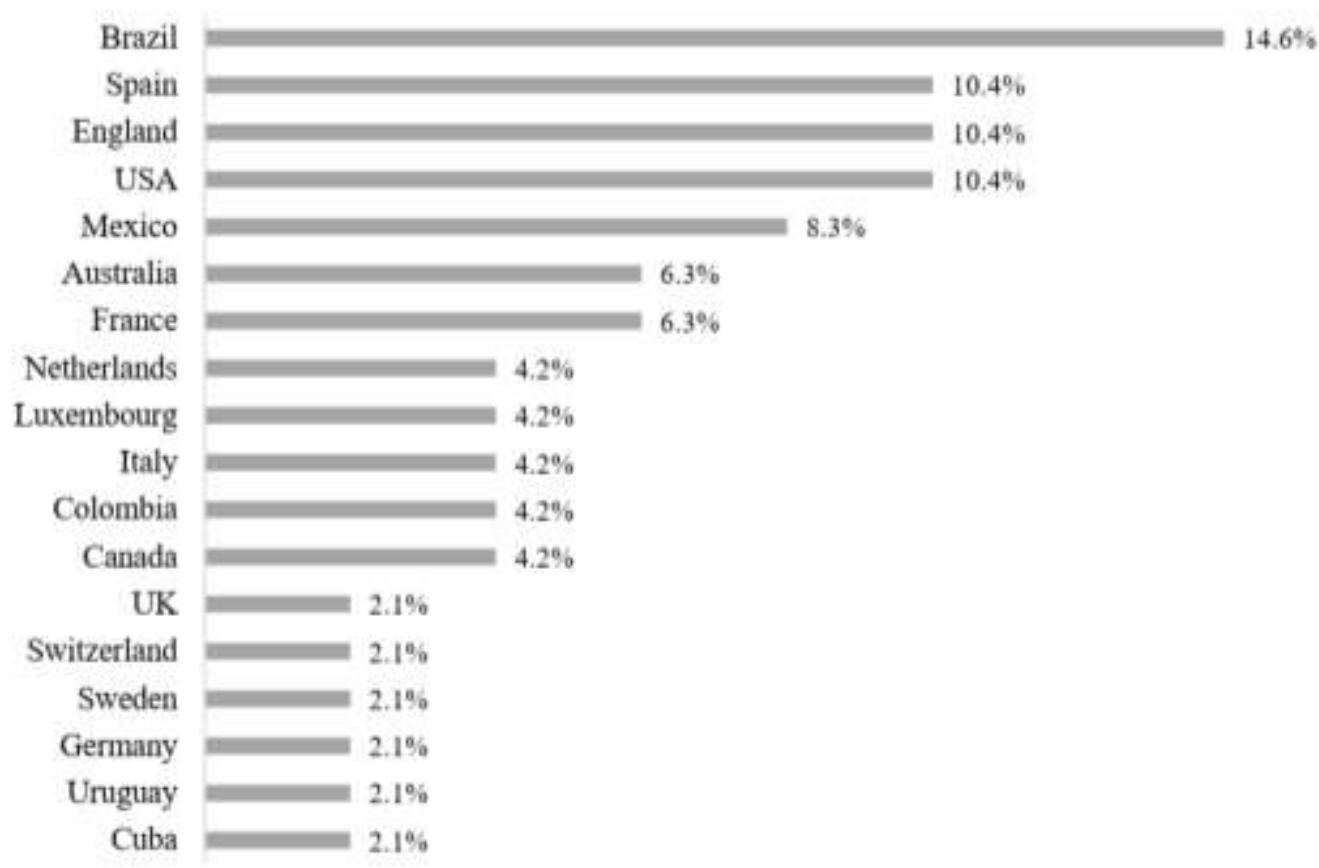

a. Contribution of countries in health and nutrition studies.

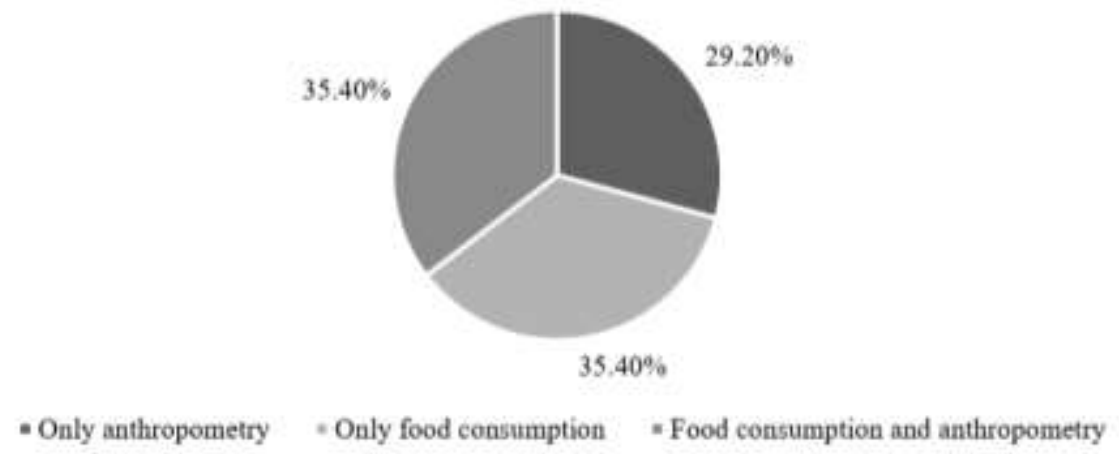

b. Methods used for assessment of food consumption and anthropometry.

Source: Authors.

The main population surveys on nutrition and health that served as the basis for the papers, alone or in comparison with other surveys, were: the National Health and Nutrition Examination Survey (NHANES; USA) (Bays et al., 2007; Cifelli et al., 2016; Guendelman et al., 2013; Kant; Graubard, 2015; Tande et al., 2009), with five derived studies; Anthropometry, Intake and Energy Balance in Spain (ANIBES; Spain) (Nissensohn et al., 2016, 2017; Ruiz et al., 2015, 2016) and National Survey of Health and Development (NSH; England) (Cooper et al., 2014; Pot et al., 2014; Pot et al., 2015; Prynne et al., 2009) with four articles each; Italian National Food Consumption Survey (INRAN-SCAI; Italy) (Leclercq et al., 2009; Nissensohn et al., 2017; Sette et al., 2018), Brazilian Household Budget Survey/Pesquisa de Orçamentos Familiares (Brazil) (Bezerra \& Sichieri, 2011; Pereira, Duffey, Sichieri, 2014; Sichieri et al., 2015) with three publications; National Demography and Health Survey/Pesquisa Nacional de Demografia e Saúde (PNDS; Brazil) (Meller et al., 2014; Pavão, 2013), Encuesta Nacional de Salud y Nutrición (ENSANUT; Mexico) (Barquera et al., 2010; Ponce et al., 2013), Encuesta Nacional de Situación Nutricional (ENSIN;Colombia) (Acosta, 2013; Kordas et al., 2012), Individual and national study on food consumption (INCA 2; France) (Gazan et al., 2016; Tressou et al., 2016),British National Diet and Nutrition Survey (NDNS; UK/England)(Marcenes et al., 2003; Whitton et al, 2011) and Observation of Cardiovascular Risk Factors in Luxembourg 
(ORISCAV-LUX; Luxembourg)(Alkerwi et al, 2015; Alkerwi et al., 2015a) with two publications each. The following served as a basis for one publication each: Dutch National Food Consumption Survey (DNFCS; Netherlands) (Sluik et al, 2014), NutriNet-Santé Dataset (France) (Nissensohn et al., 2017), ENDS (Colombia) (Acosta, 2013), Australian Health Survey (Australia) (Bell et al., 2015), Estudio Nacional de Salud y Envejecimiento en México (ENASEM; Mexico) (Melano-Carranza et al., 2008), Encuesta Nacional de Ingesta Dietetica (ENIDE; Spain)(Beltrán-de-Miguel et al., 2015), Étude Nationa Le Nutrition Santé(ENNS; France) (Vernay et al., 2009), Segunda Encuesta Nacional de Sobrepeso y Obesidad (ENSO 2; Uruguay) (Pisabarro et al., 2009), Food Habits of Canadians Survey (Canada) (Gray-Donald et al., 2000), Mexican National Health and Nutrition Survey 2006 (Mexico) (Barquera et al., 2009), National Screening on Malnutrition (Netherlands) (Kruizenga HM, Wierdsma NJ, Vanbokhorst MAE, De Vander Schueren, Hollander HJ, 2003), Nielsen Media Research (Australia) (Mohr et al., 2007), National Nutrition and Physical Activity Survey (NNPAS; Australia) (Lei et al., 2016), German National Nutrition Survey (NVS II; Germany) (Gose et al., 2016), German National Nutrition Monitoring (NEMONIT;Germany) (Gose et al., 2016), National Health Research/Pesquisa Nacional de Saúde(PNS;Brazil) (VelasquezMelendez et al., 2015), Research Social Dimension of Inequalities/Pesquisa Dimensão Social das Desigualdades(PDSD; Brazil) (Pavão, 2013), Segunda Encuesta Nacional sobre Factores de Riesgo y Afecciones Crónicas no Transmisibles de la Población Cubana (Cuba) (Acosta et al, 2006), Study to Help Improve Early Evaluation and Management of Risk Factors Leading to Diabetes (SHIELD;USA)(Bays et al., 2007), The National Survey Riksmaten (Sweden) (Bjermo et al, 2013) and The Swiss Health Survey (Switzerland)(Meier et al., 2010).

\section{Methods used for assessment of food consumption and anthropometry}

Food record was the more frequent survey method, used in 16 studies (Bezerra \& Sichieri, 2011; Bjermo et al, 2013; Gazan et al., 2016; Leclercq et al., 2009; Marcenes et al., 2003; Nissensohn et al., 2017; Pereira, Duffey, Sichieri, 2014; Pot et al., 2014; Pot et al., 2015; Prynne et al., 2009; Ruiz et al., 2016, 2015; Sette et al., 2018; Sichieri et al., 2015; Tressou et al., 2016; Whitton et al, 2011), followed by the R24h, used in 11 studies (Barr et al., 2016; Bell et al., 2015; Beltrán-de-Miguel et al., 2015; Cifelli et al., 2016; Gose et al., 2016; Kant, Graubard, 2015; Lei et al., 2016; Pisabarro et al., 2009; Sluik et al, 2014; Tande et al., 2009; Vernay et al., 2009), the FFQ, included in seven articles (Alkerwi et al., 2015; Alkerwi et al., 2015a; Bjermo et al, 2013; Meier et al., 2010; Mohr et al., 2007; Ponce et al., 2013; Velasquez-Melendez et al., 2015) and, finally, the food diary, applied in three studies (Nissensohn et al., 2016, 2017; Vernay et al., 2009). The application frequency varied according to the type of food survey conducted. The number of food records ranged from two to seven days, the R24h was applied from one to five times, and the food diary was used for three days, in all studies.

Nine of the 14 articles that used the food record performed four or more assessments (Bezerra \& Sichieri, 2011; Bjermo et al, 2013; Gazan et al., 2016; Marcenes et al., 2003; Pot et al., 2014; Pot et al., 2015; Prynne et al., 2009; Tressou et al., 2016; Whitton et al., 2011). Along with the R24h, 11 papers applied this method, at least two applications were performed in at least seven studies (Bell et al., 2015; Cifelli et al., 2016; Gose et al., 2016; Gray-Donald et al., 2000; Lei et al., 2016; Melano-Carranza et al., 2008; Sluik et al., 2014), as recommended by the National Cancer Institute (2015). The evaluation of habitual consumption, dietary pattern, ingestion of foods or food groups, energy, and macro and/or micronutrients, were the purpose of the application of the R24h in nine studies (Bell et al., 2015; Beltrán-de-Miguel et al., 2015; Cifelli et al., 2016; Gose et al., 2016; Gray-Donald et al., 2000; Kant, Graubard, 2015; Lei et al., 2016; Sluik et al., 2014; Tande et al., 2009). The R24h was used to evaluate consumption of alcohol and breakfast (being a consumer or not) in two other papers (Barr et al., 2016; Vernay et al., 2009).

In relation to anthropometry, BMI was the indicator used in all 30 studies designed to assess anthropometric nutritional status(Acosta, 2013; Acosta et al, 2006; Barquera et al., 2009, 2010; Barr et al., 2016; Bays et al., 2007; Bell et al., 
2015; Bezerra \& Sichieri, 2011; Cooper et al., 2014; Ferreira \& Benicio, 2015; Guendelman et al., 2013; Kant, Graubard, 2015; Kordas et al., 2012; Kruizenga et al, 2003; Leclercq et al., 2009; Lei et al., 2016; Marcenes et al., 2003; Meier et al., 2010; Melano-Carranza et al., 2008; Meller et al., 2014; Nissensohn et al., 2017; Pavão, 2013; Pisabarro et al., 2009; Ponce et al., 2013; Pot et al., 2015; Sette et al., 2018; Sichieri et al., 2015; Sluik et al., 2014; Velasquez-Melendez et al., 2015; Vernay et al., 2009), with the exception of the study of Tande et al.(Tande et al., 2009), which evaluated only waist circumference. Some of the studies also evaluated other body measurements, such as waist circumference (Acosta et al, 2006; Barquera et al., 2009; Bell et al., 2015; Meller et al., 2014; Nissensohn et al., 2017) and waist-hip ratio (Ferreira \& Benício, 2015). About the BMI evaluation, 20 papers used the classification proposed by the World Health Organization (WHO) (Acosta, 2013; Acosta et al, 2006; Barquera et al., 2009, 2010; Barr et al., 2016; Bays et al., 2007; Bell et al., 2015; Bezerra \& Sichieri, 2011; Cooper et al., 2014; Ferreira \& Benicio, 2015; Guendelman et al., 2013; Kant ; Graubard, 2015; Kordas et al., 2012; Kruizenga et al, 2003; Lei et al., 2016; Marcenes et al., 2003; Meier et al., 2010; Melano-Carranza et al., 2008; Meller et al., 2014; Nissensohn et al., 2017; Pavão, 2013; Pisabarro et al., 2009; Ponce et al., 2013; Pot et al., 2015; Sichieri et al., 2015; Velasquez-Melendez et al., 2015; Vernay et al., 2009). The studies of Melano-Carranza et al. (Melano-Carranza et al., 2008), Nissensohn et al. (Nissensohn et al., 2017), Pot et al. (Pot et al., 2015), Cooper et al. (Cooper et al., 2014), Sluik et al. (Sluik et al, 2014), Sette et al. (Sette et al., 2018), and Leclercq et al. (Leclercq et al., 2009) only reported the mean BMI values in the population studied. Acosta et al. (Acosta SJ, Sánchez et al, 2006) used the classification of the Food and Agriculture Organization of the United Nations (Shetty \& James, 1994). The study by Barr et al. (Barr et al., 2016) did not describe the classification used. Other studies used classifications of other international institutions such as the International Obesity Task Force (Pisabarro et al., 2009) and the National Institutes of Health Clinical Guidelines (Bays et al., 2007).

With regard to the quality of the measures for composition of BMI, 11 papers reported that interviewers/researchers were trained to perform the measurements (Barquera et al., 2009, 2010; Barr et al., 2016; Cooper et al., 2014; Guendelman et al., 2013; Kordas et al., 2012; Meller et al., 2014; Pisabarro et al., 2009; Ponce et al., 2013; Pot et al., 2015; Vernay et al., 2009), four studies reported the calibration of equipment (Acosta SJ, Sánchez et al, 2006; Kordas et al., 2012; Meller et al., 2014; Ponce et al., 2013), and only two articles (Ferreira \& Benicio, 2015; Meller et al., 2014) reported performing two repetitions of each measurement of weight and height, as standardized by the WHO for collection of these data. Only the study of Meller et al. (Meller et al., 2014) reported all the information about the survey (training of the interviewers, calibration of equipment, and replication of anthropometric measures). 
Research, Society and Development, v. 11, n. 2, e27211225434, 2022

(CC BY 4.0) | ISSN 2525-3409 | DOI: http://dx.doi.org/10.33448/rsd-v11i2.25434

Table 1. Characteristics of the studies and population-based surveys on health and nutrition, performed in the Americas, Europe, and Oceania, from 1997 to 2017.

\begin{tabular}{|c|c|c|c|c|c|c|c|c|c|c|c|}
\hline \multicolumn{8}{|c|}{ Characteristics of the Studies } & \multicolumn{4}{|c|}{ Characteristics of surveys } \\
\hline Author/Year & Continent & Country & $\begin{array}{l}\text { Study } \\
\text { Design }\end{array}$ & $\mathbf{n}$ & Main & $\begin{array}{c}\text { Age range } \\
\text { (years) }\end{array}$ & $\begin{array}{c}\text { Score/ } \\
\text { Methodological } \\
\text { quality }\end{array}$ & Survey & Variables & $\begin{array}{l}\text { BMI cut-off } \\
\text { points }\end{array}$ & $\mathbf{N}^{\circ}$ Records \\
\hline $\begin{array}{l}\text { Acosta K., } \\
\text { 2013. }\end{array}$ & Americas & Colombia & $\begin{array}{l}\text { Cross- } \\
\text { sectional }\end{array}$ & 150,733 & $\begin{array}{lrr}\text { To calculate } & \text { obesity } \\
\text { concentration } & \text { indices } \\
\text { among adults } & \text { in } \\
\text { Colombia. } & & \end{array}$ & $18-64$ & 7 (moderate) & $\begin{array}{l}\text { ENDS (2005) } \\
\text { and ENSIN } \\
(2010)\end{array}$ & BMI & WHO, 1995 & - \\
\hline $\begin{array}{l}\text { Acosta S. et } \\
\text { al., } 2005 .\end{array}$ & Americas & Cuba & $\begin{array}{l}\text { Cross- } \\
\text { sectional }\end{array}$ & 19,519 & $\begin{array}{l}\text { To evaluate the nutritional } \\
\text { status of the resident } \\
\text { population in the urban } \\
\text { area of Cuba and compare } \\
\text { evolutionarily the changes } \\
\text { experienced in relation to } \\
\text { the previous survey. }\end{array}$ & $>20$ & 6 (moderate) & $\begin{array}{l}\text { Segunda } \\
\text { Encuesta } \\
\text { Nacional } \\
\text { sobre } \\
\text { Factores de } \\
\text { Riesgo y } \\
\text { Afecciones } \\
\text { Crónicas no } \\
\text { Transmisibles } \\
\text { de la } \\
\text { Población } \\
\text { Cubana } \\
\text { (2000-2001) }\end{array}$ & $\begin{array}{l}\mathrm{BMI} \\
\mathrm{CC} \\
\mathrm{CQ}\end{array}$ & $\begin{array}{l}\text { FAO, } 1994 \\
\text { WHO, } 1998\end{array}$ & - \\
\hline $\begin{array}{l}\text { Alkerwi A. } \\
\text { et al, 2015. }\end{array}$ & Europe & $\begin{array}{l}\text { Luxembour } \\
\mathrm{g}\end{array}$ & $\begin{array}{l}\text { Cross- } \\
\text { sectional }\end{array}$ & 1,352 & $\begin{array}{l}\text { To examine the } \\
\text { association between } \\
\text { nutritional awareness and } \\
\text { diet quality, as indicated } \\
\text { by energy density, dietary } \\
\text { diversity and adequacy to } \\
\text { achiever dietary } \\
\text { recommendations, while } \\
\text { considering the } \\
\text { potentially important role } \\
\text { of socioeconomic status }\end{array}$ & $18-69$ & 7 (moderate) & $\begin{array}{l}\text { ORISCAV- } \\
\text { LUX } \\
(2007-2008)\end{array}$ & $\begin{array}{l}\text { Food } \\
\text { consumption }\end{array}$ & - & $\begin{array}{l}\text { Semi- } \\
\text { quantitative } \\
\text { FFQ }\end{array}$ \\
\hline Alkerwi A. & Europe & Luxembour & Cross- & 1,351 & $\begin{array}{l}\text { To compare the ability of } \\
\text { five diet quality indices, }\end{array}$ & $18-69$ & 7 (moderate) & $\begin{array}{l}\text { ORISCAV- } \\
\text { LUX (2007- }\end{array}$ & Food & - & QFC \\
\hline
\end{tabular}


Research, Society and Development, v. 11, n. 2, e27211225434, 2022

(CC BY 4.0) | ISSN 2525-3409 | DOI: http://dx.doi.org/10.33448/rsd-v11i2.25434

\begin{tabular}{|c|c|c|c|c|c|c|c|c|c|}
\hline et al, 2015a. & $\mathrm{g}$ & sectional & & $\begin{array}{l}\text { namely the } \\
\text { Recommendation } \\
\text { Compliance Index, Diet } \\
\text { Quality Index- } \\
\text { International, Dietary } \\
\text { Approaches to Stop } \\
\text { Hypertension, } \\
\text { Mediterranean Diet Score, } \\
\text { and Dietary Inflammatory } \\
\text { Index, to detect changes } \\
\text { in chronic disease risk } \\
\text { biomarkers. }\end{array}$ & & 2009) & consumption & & \\
\hline $\begin{array}{l}\text { Barquera S. Americas } \\
\text { et al, 2009. }\end{array}$ & Mexico & $\begin{array}{l}\text { Cross- } \\
\text { sectional }\end{array}$ & 33,023 & $\begin{array}{l}\text { To estimate the }>20 \\
\text { prevalence of overweight, } \\
\text { obesity and central } \\
\text { adiposity in Mexico, and } \\
\text { to explore trends } \\
\text { compared to the previous } \\
\text { Mexican National Health } \\
\text { Survey and to Mexican- } \\
\text { Americans. }\end{array}$ & 8 (high) & $\begin{array}{l}\text { Mexican } \\
\text { National } \\
\text { Health and } \\
\text { Nutrition } \\
\text { Survey } \\
(2006)\end{array}$ & $\begin{array}{l}\text { BMI } \\
\text { CC }\end{array}$ & WHO, 1998 & - \\
\hline $\begin{array}{l}\text { Barquera S. Americas } \\
\text { et al, 2010. }\end{array}$ & Mexico & $\begin{array}{l}\text { Cross- } \\
\text { sectional }\end{array}$ & 14,630 & $\begin{array}{l}\text { To describe the }>20 \\
\text { prevalence of } \\
\text { hypertension among } \\
\text { Mexican adults, and to } \\
\text { compare to that observed } \\
\text { among Mexican- } \\
\text { Americans living in the } \\
\text { US. }\end{array}$ & 8 (high) & $\begin{array}{l}\text { ENSANUT } \\
(2006)\end{array}$ & BMI & WHO, 1998 & - \\
\hline $\begin{array}{l}\text { Barr S. et al, Americas } \\
\text { 2016. }\end{array}$ & Canada & $\begin{array}{l}\text { Cross- } \\
\text { sectional }\end{array}$ & 12,337 & $\begin{array}{l}\text { To examine the }>18 \\
\text { association of breakfast } \\
\text { consumption, and the type } \\
\text { of breakfast consumed, } \\
\text { with body mass index and } \\
\text { prevalence rates and odds } \\
\text { ratios of } \\
\text { overweight/obesity of } \\
\text { among Canadian adults. }\end{array}$ & 7 (moderate) & $\begin{array}{l}\text { Canadian } \\
\text { Community } \\
\text { Health } \\
\text { Survey Cycle } \\
2.2(2004)\end{array}$ & $\begin{array}{l}\text { Dietary intake } \\
\text { BMI }\end{array}$ & $\begin{array}{lr}\text { BMI > } 25.0 \text { for } \\
\text { definition } & \text { of } \\
\text { overweight/obesity } \\
\text { in all age groups }\end{array}$ & R24h 1 day \\
\hline
\end{tabular}


Research, Society and Development, v. 11, n. 2, e27211225434, 2022

(CC BY 4.0) | ISSN 2525-3409 | DOI: http://dx.doi.org/10.33448/rsd-v11i2.25434

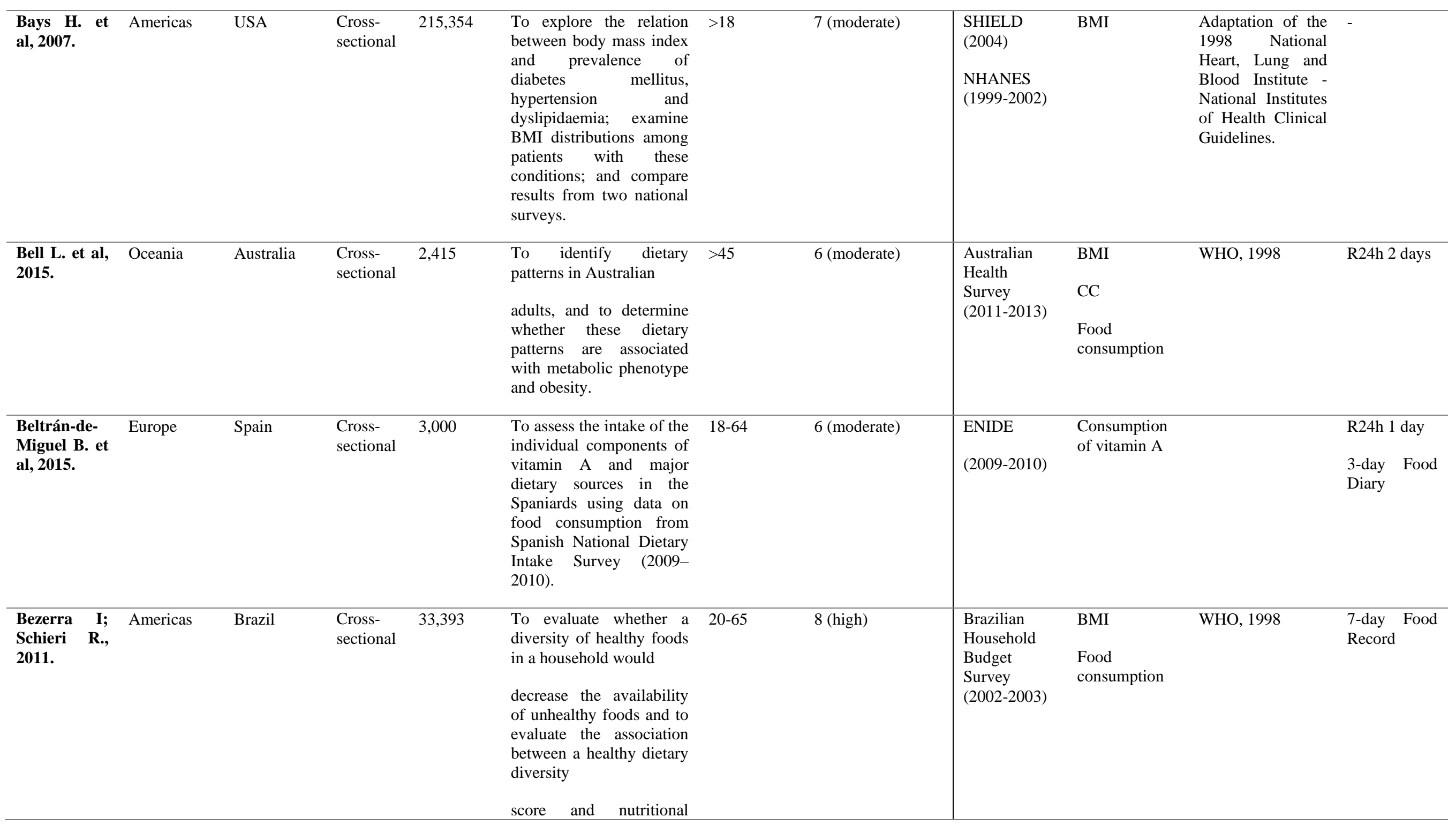


Research, Society and Development, v. 11, n. 2, e27211225434, 2022

(CC BY 4.0) | ISSN 2525-3409 | DOI: http://dx.doi.org/10.33448/rsd-v11i2.25434

\begin{tabular}{|c|c|c|c|c|c|c|c|c|c|c|c|}
\hline & & & & & status among adults. & & & & & & \\
\hline $\begin{array}{l}\text { Bjermo H. } \\
\text { et al, 2013. }\end{array}$ & Europe & Sweden & $\begin{array}{l}\text { Cross- } \\
\text { sectional }\end{array}$ & 273 & $\begin{array}{l}\text { To examine the body } \\
\text { burden of lead, mercury, } \\
\text { and cadmium in blood } \\
\text { among Swedish adults } \\
\text { and the association } \\
\text { between blood levels, diet } \\
\text { and other lifestyle factors. }\end{array}$ & $18-80$ & 8 (high) & $\begin{array}{l}\text { The National } \\
\text { Survey } \\
\text { Riksmaten } \\
(2010-2011)\end{array}$ & $\begin{array}{l}\text { Food and } \\
\text { dietary } \\
\text { consumption }\end{array}$ & - & $\begin{array}{l}\text { 4-day food } \\
\text { record } \\
\text { FFQ foods } \\
\text { not widely } \\
\text { consumed }\end{array}$ \\
\hline $\begin{array}{l}\text { Cifelli C. et } \\
\text { al, 2016. }\end{array}$ & Americas & USA & $\begin{array}{l}\text { Cross- } \\
\text { sectional }\end{array}$ & $17,387^{*}$ & $\begin{array}{l}\text { To use national survey } \\
\text { data to model different } \\
\text { dietary scenarios to assess } \\
\text { the potential effects of } \\
\text { increasing plant-based } \\
\text { foods (and concomitantly } \\
\text { decreasing animal foods) } \\
\text { or dairy foods on } \\
\text { macronutrient intake and } \\
\text { nutrient adequacy. }\end{array}$ & $\begin{array}{l}2-18 \text { and } \\
>19\end{array}$ & 7 (moderate) & $\begin{array}{l}\text { NHANES } \\
(2007-2010)\end{array}$ & $\begin{array}{l}\text { Food and } \\
\text { dietary } \\
\text { consumption }\end{array}$ & - & $\begin{array}{l}\text { R24h } 2 \text { days } \\
\text { (in person }+ \\
\text { telephone } \\
\text { contact) }\end{array}$ \\
\hline $\begin{array}{l}\text { Cooper R. et } \\
\text { al, 2014. }\end{array}$ & Europe & England & $\begin{array}{l}\text { Cross- } \\
\text { sectional }\end{array}$ & $\begin{array}{l}2,229 * \\
(1,511 \\
\text { adults/ } \\
\text { elderly) }\end{array}$ & $\begin{array}{l}\text { To examine the } \\
\text { associations of body mass } \\
\text { index from age } 15 \text { years } \\
\text { onwards with low muscle } \\
\text { mass, strength, and } \\
\text { quality in early old age. }\end{array}$ & $\begin{array}{l}15,20,26, \\
36,43,53, \\
60-64\end{array}$ & 6 (moderate) & $\begin{array}{ll}\text { NSHD } & \text { (data } \\
\text { from } & 1946 \\
\text { cohort) } & \end{array}$ & BMI & Mean BMI & - \\
\hline $\begin{array}{l}\text { Ferreira } \\
\text { Benício M, } \\
\text { 2015. }\end{array}$ & Americas & Brazil & $\begin{array}{l}\text { Cross- } \\
\text { sectional }\end{array}$ & 11,961 & $\begin{array}{l}\text { To determine the } \\
\text { influence of reproductive } \\
\text { history on the prevalence } \\
\text { of } \\
\text { obesity in Brazilian } \\
\text { women and effect of } \\
\text { socioeconomic variables } \\
\text { on the association } \\
\text { between parity and excess } \\
\text { weight. }\end{array}$ & $20-49$ & 6 (moderate) & PNDS (2006) & BMI & WHO, 2000 & - \\
\hline Gazan R. et & Europe & France & Cross- & 1,918 & $\begin{array}{l}\text { To examine the } \\
\text { association between }\end{array}$ & $>18$ & 7 (moderate) & INCA 2 & $\begin{array}{l}\text { Consumption } \\
\text { of food, }\end{array}$ & - & 7-day Food \\
\hline
\end{tabular}


Research, Society and Development, v. 11, n. 2, e27211225434, 2022

(CC BY 4.0) | ISSN 2525-3409 | DOI: http://dx.doi.org/10.33448/rsd-v11i2.25434

\begin{tabular}{|c|c|c|c|c|c|c|c|c|c|c|c|}
\hline al, 2016. & & & sectional & & $\begin{array}{l}\text { drinking water intake and } \\
\text { diet quality, and to } \\
\text { analyse the adherence of } \\
\text { French men and women } \\
\text { to the European Food } \\
\text { Safety Authority } 2010 \\
\text { Adequate Intake. }\end{array}$ & & & $(2005-2007)$ & $\begin{array}{l}\text { drinks, and } \\
\text { water }\end{array}$ & & Record \\
\hline $\begin{array}{l}\text { Gose M. et } \\
\text { al, 2016. }\end{array}$ & Europe & Germany & Cohort & $1,840^{*}$ & $\begin{array}{l}\text { To assess changes in food } \\
\text { consumption and nutrient } \\
\text { intake in Germany. }\end{array}$ & $\begin{array}{l}14-65 \text { and } \\
>65\end{array}$ & 8 (high) & $\begin{array}{l}\text { NVS II } \\
(2005 / 2007) \\
\text { NEMONIT } \\
(2008-2012 / \\
2013)\end{array}$ & $\begin{array}{l}\text { Dietary } \\
\text { consumption }\end{array}$ & - & R24h 2 days \\
\hline $\begin{array}{l}\text { Gray- } \\
\text { Donald K. et } \\
\text { al, } 2000 .\end{array}$ & Americas & Canada & $\begin{array}{l}\text { Cross- } \\
\text { sectional }\end{array}$ & $\begin{array}{l}1,722 * \\
(1,544 \\
\text { adults/eld } \\
\text { erly })\end{array}$ & $\begin{array}{l}\text { To monitor whether } \\
\text { changes in dietary intake } \\
\text { have occurred since the } \\
\text { last Canadian dietary } \\
\text { survey, conducted a } \\
\text { generation ago (1970). }\end{array}$ & $\begin{array}{l}13-17 \text { and } \\
18-65\end{array}$ & 7 (moderate) & $\begin{array}{l}\text { Food Habit of } \\
\text { Canadians } \\
\text { survey (1997- } \\
\text { 1998) }\end{array}$ & $\begin{array}{l}\text { Food } \\
\text { consumption }\end{array}$ & - & $\begin{array}{l}\text { R24h - 1 day } \\
\text { (repeated in } \\
30 \% \text { of the } \\
\text { sample) } \\
\text { with the use } \\
\text { of models of } \\
\text { food } \\
\text { portions. }\end{array}$ \\
\hline $\begin{array}{l}\text { Guendelman } \\
\text { S. et al, } \\
\text { 2013. }\end{array}$ & Americas & USA & $\begin{array}{l}\text { Cross- } \\
\text { sectional }\end{array}$ & 979 & $\begin{array}{l}\text { To examine actual and } \\
\text { perceived weight in } \\
\text { national cohorts of } \\
\text { Mexican-origin adult men } \\
\text { in Mexico and the United } \\
\text { States (US). }\end{array}$ & $20-59$ & 7 (moderate) & $\begin{array}{l}\text { NHANES } \\
(2001 / 2006) \\
\text { and } \\
\text { ENSANUT } \\
(2006)\end{array}$ & $\begin{array}{l}\text { Calculated } \\
\text { BMI and self- } \\
\text { perceived BMI }\end{array}$ & WHO, 1998 & - \\
\hline $\begin{array}{l}\text { Kant A. et } \\
\text { al, 2015. }\end{array}$ & Americas & USA & $\begin{array}{l}\text { Cross- } \\
\text { sectional }\end{array}$ & 62,298 & $\begin{array}{l}\text { To examine time trends in } \\
\text { the distribution of day's } \\
\text { intake into individual } \\
\text { meal and snack behaviors } \\
\text { and related attributes in } \\
\text { the United States adult } \\
\text { population. }\end{array}$ & $20-74$ & 9 (high) & $\begin{array}{l}\text { NHANES } \\
\text { (1971-74, } \\
\text { 1976-1980, } \\
\text { 1988-1994, } \\
\text { 1999-2000, } \\
2001-2002, \\
2003-2004, \\
2005-2006, \\
2007-2008,\end{array}$ & $\begin{array}{l}\text { Food } \\
\text { consumption } \\
\text { of meals and } \\
\text { snacks } \\
\text { BMI }\end{array}$ & WHO, 1998 & $\begin{array}{l}\text { R24h } 1 \text { day } \\
\text { (in paper } \\
\text { form, } \\
\text { interview by } \\
\text { telephone, } \\
\text { computer) }\end{array}$ \\
\hline
\end{tabular}


Research, Society and Development, v. 11, n. 2, e27211225434, 2022

(CC BY 4.0) | ISSN 2525-3409 | DOI: http://dx.doi.org/10.33448/rsd-v11i2.25434

\begin{tabular}{|c|c|c|c|c|c|c|c|c|c|c|c|}
\hline & & & & & & & & $\begin{array}{l}\text { and 2009- } \\
\text { 2010) }\end{array}$ & & & \\
\hline $\begin{array}{l}\text { Kordas K. et } \\
\text { al, } 2013 \text {. }\end{array}$ & Americas & Colombia & $\begin{array}{l}\text { Cross- } \\
\text { sectional }\end{array}$ & $\begin{array}{l}3,267 * \\
(2,612 \\
\text { adults })\end{array}$ & $\begin{array}{l}\text { To investigate the } \\
\text { association among iron } \\
\text { deficiency (ID), anemia, } \\
\text { and weight status among } \\
\text { nonpregnant Colombian } \\
\text { females aged } 13-49 \mathrm{y} \text {. }\end{array}$ & $\begin{array}{l}13-17 \text { and } \\
18-49\end{array}$ & 7 (moderate) & $\begin{array}{l}\text { ENSIN } \\
(2005)\end{array}$ & BMI & WHO, 1998 & \\
\hline $\begin{array}{l}\text { Leclercq C. } \\
\text { et al, 2009. }\end{array}$ & Europe & Italy & $\begin{array}{l}\text { Cross- } \\
\text { sectional }\end{array}$ & 2,831 & $\begin{array}{l}\text { To present the main } \\
\text { results of the Italian } \\
\text { National } \\
\text { Consumption } \\
\text { INRAN-SCAI } 2005-06 .\end{array}$ & $>18$ & 8 (high) & $\begin{array}{l}\text { INRAN- } \\
\text { SCAI (2005- } \\
2006)\end{array}$ & $\begin{array}{l}\text { Food } \\
\text { consumption } \\
\text { BMI }\end{array}$ & Mean BMI & $\begin{array}{l}\text { self- } \\
\text { administered } \\
\text { 3-day food } \\
\text { record }\end{array}$ \\
\hline $\begin{array}{l}\text { Lei L. et al, } \\
2016 .\end{array}$ & Oceania & Australia & $\begin{array}{l}\text { Cross- } \\
\text { sectional }\end{array}$ & $\begin{array}{l}8,202^{*} \\
(6,326 \\
\text { adults and } \\
\text { elderly) }\end{array}$ & $\begin{array}{l}\text { To examine the AS and } \\
\text { free sugar intakes and the } \\
\text { main food sources of AS } \\
\text { among Australians. }\end{array}$ & $>02$ & 8 (high) & $\begin{array}{l}\text { NNPAS } \\
(2011-2012)\end{array}$ & $\begin{array}{l}\text { BMI } \\
\text { Food } \\
\text { consumption }\end{array}$ & WHO, 1998 & $\begin{array}{l}\text { R24h } 2 \text { days } \\
\text { (in person }+ \\
\text { telephone } \\
\text { contact) }\end{array}$ \\
\hline $\begin{array}{l}\text { Marcenes } \\
\text { W. et al, } \\
\text { 2003. }\end{array}$ & Europe & UK & $\begin{array}{l}\text { Cross- } \\
\text { sectional }\end{array}$ & 949 & $\begin{array}{l}\text { To review the major } \\
\text { findings from a large } \\
\text { representative and } \\
\text { comprehensive national } \\
\text { survey in Great Britain to } \\
\text { which the numbers of } \\
\text { teeth and dentures } \\
\text { affected older people's } \\
\text { ease of eating, nutrient }\end{array}$ & $>65$ & 6 (moderate) & $\begin{array}{l}\text { NDNS } \\
(1998)\end{array}$ & $\begin{array}{l}\text { BMI } \\
\text { Food and } \\
\text { dietary } \\
\text { consumption }\end{array}$ & WHO, 1998 & $\begin{array}{l}\text { 4-day Heavy } \\
\text { food record }\end{array}$ \\
\hline
\end{tabular}


Research, Society and Development, v. 11, n. 2, e27211225434, 2022

(CC BY 4.0) | ISSN 2525-3409 | DOI: http://dx.doi.org/10.33448/rsd-v11i2.25434

\begin{tabular}{|c|c|c|c|c|c|c|c|c|c|c|c|}
\hline & & & & & $\begin{array}{l}\text { intake, nutritional status, } \\
\text { and body mass index. }\end{array}$ & & & & & & \\
\hline $\begin{array}{l}\text { Meier M. et } \\
\text { al, 2010. }\end{array}$ & Europe & Switzerland & $\begin{array}{l}\text { Cross- } \\
\text { sectional }\end{array}$ & 1,786 & $\begin{array}{l}\text { To assess whether Swiss } \\
\text { residents aged 15-24 } \\
\text { years follow current } \\
\text { nutritional guidelines and } \\
\text { whether differences exist } \\
\text { according to gender and } \\
\text { weight status. }\end{array}$ & $15-24$ & 9 (high) & $\begin{array}{l}\text { The Swiss } \\
\text { Health } \\
\text { Survey } \\
(2007)\end{array}$ & $\begin{array}{l}\text { BMI } \\
\text { Food } \\
\text { consumption }\end{array}$ & WHO, 1998 & FFQ \\
\hline $\begin{array}{l}\text { Melano- } \\
\text { Carranza } \\
\text { E., } 2008\end{array}$ & Americas & Mexico & $\begin{array}{l}\text { Cross- } \\
\text { sectional }\end{array}$ & 2,029 & $\begin{array}{l}\text { To determine factors } \\
\text { associated with failure to } \\
\text { adhere to treatment for } \\
\text { diagnosed hypertension } \\
\text { among a representative } \\
\text { sample of older Mexican } \\
\text { adults living } \\
\text { in the community. }\end{array}$ & $>65$ & 7 (moderate) & $\begin{array}{l}\text { ENASEM } \\
(2001)\end{array}$ & BMI & Mean BMI & - \\
\hline $\begin{array}{l}\text { Meller F. et } \\
\text { al, 2014. }\end{array}$ & Americas & Brazil & $\begin{array}{l}\text { Cross- } \\
\text { sectional }\end{array}$ & 14,101 & $\begin{array}{l}\text { To evaluate the } \\
\text { association between waist } \\
\text { circumference } \\
\text { and body mass index of } \\
\text { Brazilian } \\
\text { women of childbearing } \\
\text { age studied in the } \\
\text { National Demographic } \\
\text { and Health Survey, in } \\
2006 \text {. }\end{array}$ & $18-49$ & 6 (moderate) & PNDS (2006) & $\mathrm{BMI} / \mathrm{CC}$ & WHO, 1998 & - \\
\hline $\begin{array}{l}\text { Mohr P. et } \\
\text { al, 2007. }\end{array}$ & Oceania & Australia & $\begin{array}{l}\text { Cross- } \\
\text { sectional }\end{array}$ & $20,527 *$ & $\begin{array}{l}\text { To identify key predictors } \\
\text { of fast-food consumption } \\
\text { from a range of } \\
\text { demographic, attitudinal, } \\
\text { personality and lifestyle } \\
\text { variables. }\end{array}$ & $>14$ & 6 (moderate) & $\begin{array}{l}\text { Nielsen } \\
\text { Media } \\
\text { Research } \\
(2004-2005)\end{array}$ & $\begin{array}{l}\text { Food } \\
\text { consumption }\end{array}$ & - & $\begin{array}{l}\text { FFQ fast } \\
\text { food }\end{array}$ \\
\hline
\end{tabular}


Research, Society and Development, v. 11, n. 2, e27211225434, 2022

(CC BY 4.0) | ISSN 2525-3409 | DOI: http://dx.doi.org/10.33448/rsd-v11i2.25434

\begin{tabular}{|c|c|c|c|c|c|c|c|c|c|c|c|}
\hline $\begin{array}{l}\text { Nissensohn } \\
\text { M. et al, } \\
\text { 2016. }\end{array}$ & Europe & Spain & $\begin{array}{l}\text { Cross- } \\
\text { sectional }\end{array}$ & $\begin{array}{l}2,007 * \\
(1,784 \\
\text { adults/ } \\
\text { elderly) }\end{array}$ & $\begin{array}{l}\text { To quantify the total } \\
\text { water and beverage } \\
\text { intake, and to explore } \\
\text { associations between the } \\
\text { types of beverage } \\
\text { consumed and energy } \\
\text { intake. }\end{array}$ & $9-75$ & 8 (high) & $\begin{array}{l}\text { ANIBES } \\
(2013)\end{array}$ & $\begin{array}{l}\text { Consumption } \\
\text { of foods and } \\
\text { beverages }\end{array}$ & - & $\begin{array}{l}\text { 3-days } \\
\text { Food Record } \\
\text { (food diary) } \\
\text { (using a } \\
\text { digital } \\
\text { camera, } \\
\text { tablet, } \\
\text { interview by } \\
\text { phone, or } \\
\text { form) }\end{array}$ \\
\hline $\begin{array}{l}\text { Nissensohn } \\
\text { M. et al, } \\
\text { 2017. }\end{array}$ & Europe & Spain & $\begin{array}{l}\text { Cross- } \\
\text { sectional }\end{array}$ & 99,111 & $\begin{array}{l}\text { To compare the average } \\
\text { daily consumption of } \\
\text { foods and beverages in } \\
\text { adults of selective } \\
\text { samples of the European } \\
\text { Union population to } \\
\text { understand the } \\
\text { contribution of these to } \\
\text { the total water intake, } \\
\text { evaluate if the EU adult } \\
\text { population consumes } \\
\text { adequate amounts of total } \\
\text { water according to the } \\
\text { current guidelines, and to } \\
\text { illustrate the real water } \\
\text { intake in Europe. }\end{array}$ & $18-75$ & 6 (moderate) & $\begin{array}{l}\text { ANIBES } \\
\text { (Spain } \\
\text { 2013); } \\
\text { INRAN- } \\
\text { SCAI Dataset } \\
\text { (Italy - 2005- } \\
\text { 2006); } \\
\text { NutriNet- } \\
\text { Santé Dataset } \\
\text { (France - } \\
\text { 2009-2010) }\end{array}$ & $\begin{array}{l}\text { BMI } \\
\text { CC } \\
\text { Consumption } \\
\text { of foods and } \\
\text { beverages }\end{array}$ & Mean BMI & 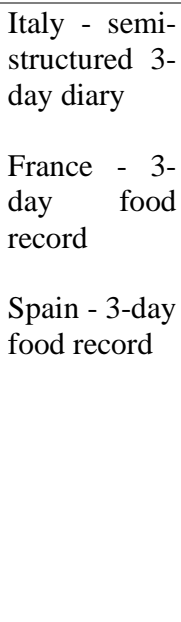 \\
\hline $\begin{array}{l}\text { Pavão A. et } \\
\text { al, 2013. }\end{array}$ & Americas & Brazil & $\begin{array}{l}\text { Cross- } \\
\text { sectional }\end{array}$ & 12,324 & $\begin{array}{l}\text { To investigate the } \\
\text { association between self- } \\
\text { rated health and social } \\
\text { and demographic factors, } \\
\text { health behavior, and } \\
\text { morbidity. }\end{array}$ & $>20$ & 7 (moderate) & PDSD (2008) & BMI & WHO, 1998 & - \\
\hline $\begin{array}{l}\text { Pereira R. et } \\
\text { al, 2014. }\end{array}$ & Americas & Brazil & $\begin{array}{l}\text { Cross- } \\
\text { sectional }\end{array}$ & $\begin{array}{l}34,003^{*} \\
(26,522\end{array}$ & $\begin{array}{l}\text { To examine the patterns } \\
\text { of consumption of foods } \\
\text { high in solid fats and } \\
\text { added sugars in the first }\end{array}$ & $>10$ & 6 (moderate) & $\begin{array}{l}\text { Brazilian } \\
\text { Household } \\
\text { Budget } \\
\text { Survey }\end{array}$ & $\begin{array}{l}\text { Consumption } \\
\text { of saturated } \\
\text { and trans fats }\end{array}$ & - & $\begin{array}{l}\text { 2-day Food } \\
\text { Record }\end{array}$ \\
\hline
\end{tabular}


Research, Society and Development, v. 11, n. 2, e27211225434, 2022

(CC BY 4.0) | ISSN 2525-3409 | DOI: http://dx.doi.org/10.33448/rsd-v11i2.25434

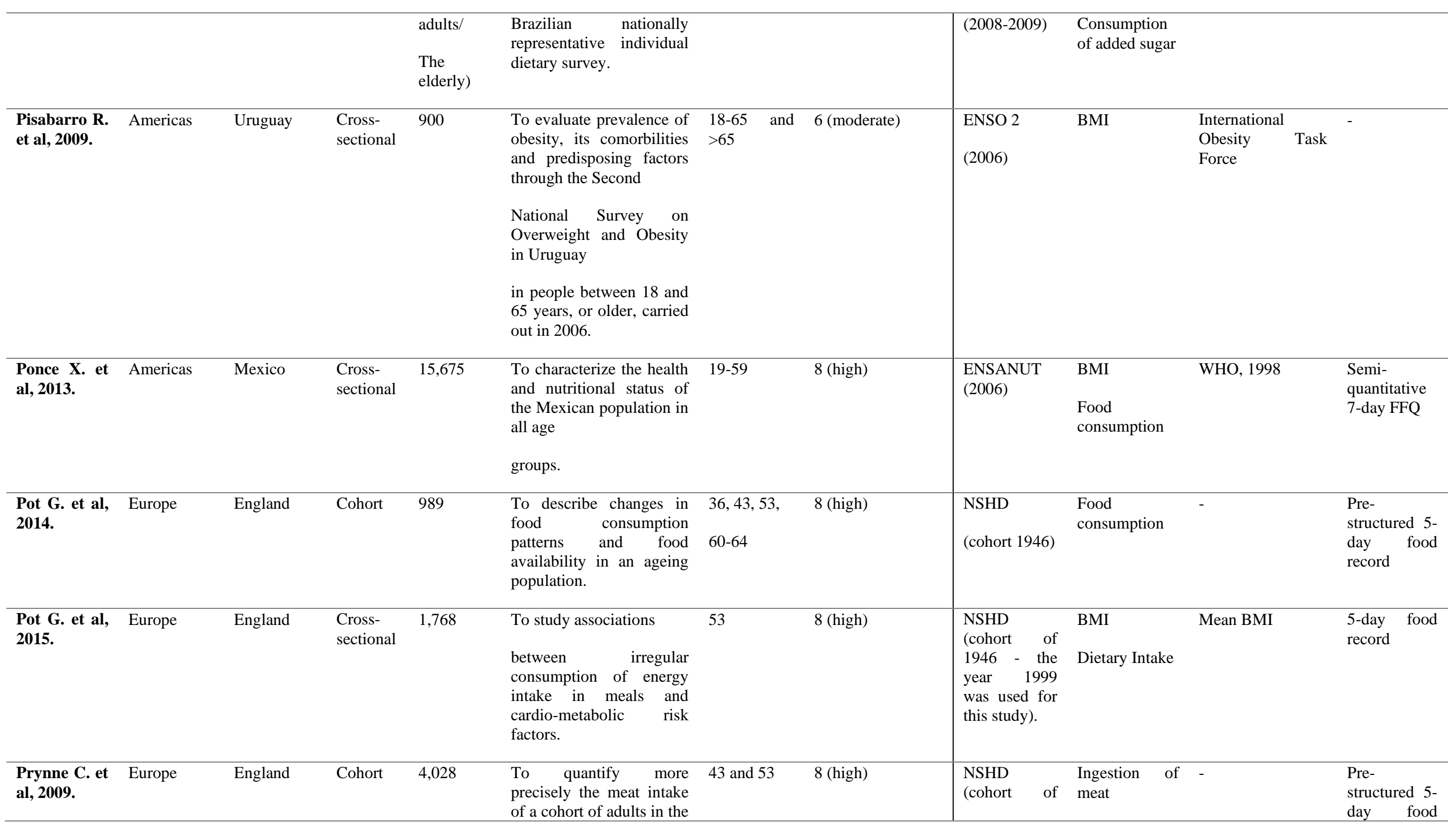


Research, Society and Development, v. 11, n. 2, e27211225434, 2022

(CC BY 4.0) | ISSN 2525-3409 | DOI: http://dx.doi.org/10.33448/rsd-v11i2.25434

\begin{tabular}{|c|c|c|c|c|c|c|c|c|c|c|c|}
\hline & & & & & $\begin{array}{l}\text { UK by disaggregating } \\
\text { composite meat dishes. }\end{array}$ & & & 1946) & & & record \\
\hline $\begin{array}{l}\text { Ruiz E. et al, } \\
2015\end{array}$ & Europe & Spain & $\begin{array}{l}\text { Cross- } \\
\text { sectional }\end{array}$ & $\begin{array}{l}2,009 * \\
(1,861 \\
\text { adults/eld } \\
\text { erly) }\end{array}$ & $\begin{array}{l}\text { To contribute to updating } \\
\text { data of dietary energy } \\
\text { intake } \\
\text { and its main sources from } \\
\text { food and beverages, } \\
\text { according to gender and } \\
\text { age. }\end{array}$ & $9-75$ & 6 (moderate) & $\begin{array}{l}\text { ANIBES } \\
(2013)\end{array}$ & $\begin{array}{l}\text { Consumption } \\
\text { of energy and } \\
\text { nutrients } \\
\text { Food } \\
\text { consumption }\end{array}$ & - & $\begin{array}{l}\text { 3-day food } \\
\text { record (A } \\
\text { three-day } \\
\text { dietary } \\
\text { record) (with } \\
\text { the use of } \\
\text { digital } \\
\text { camera, } \\
\text { tablet, } \\
\text { interview by } \\
\text { phone, or } \\
\text { form) }\end{array}$ \\
\hline $\begin{array}{l}\text { Ruiz E. et al, } \\
2016 .\end{array}$ & Europe & Spain & $\begin{array}{l}\text { Cross- } \\
\text { sectional }\end{array}$ & $\begin{array}{l}2,009^{*} \\
(1,861 \\
\text { adults/eld } \\
\text { erly) }\end{array}$ & $\begin{array}{l}\text { To analyze dietary } \\
\text { macronutrient intake and } \\
\text { its main sources } \\
\text { according to sex and age. }\end{array}$ & $9-75$ & 6 (moderate) & $\begin{array}{l}\text { ANIBES } \\
(2013)\end{array}$ & $\begin{array}{l}\text { Consumption } \\
\text { of foods and } \\
\text { beverages } \\
\text { Dietary Intake }\end{array}$ & - & $\begin{array}{l}\text { 3-day Food } \\
\text { Record }\end{array}$ \\
\hline $\begin{array}{l}\text { Sette S. et al, } \\
\text { 2011. }\end{array}$ & Europe & Italy & $\begin{array}{l}\text { Cross- } \\
\text { sectional }\end{array}$ & 2,830 & $\begin{array}{l}\text { To describe energy and } \\
\text { nutrient intakes in Italy. }\end{array}$ & $>18$ & 7 (moderate) & $\begin{array}{l}\text { INRAN- } \\
\text { SCAI (2005- } \\
2006)\end{array}$ & $\begin{array}{l}\text { Energy, } \\
\text { macro, and } \\
\text { micronutrients } \\
\text { Alcohol intake } \\
\text { BMI }\end{array}$ & Mean BMI & $\begin{array}{l}\text { self- } \\
\text { administered } \\
\text { 3-day food } \\
\text { record }\end{array}$ \\
\hline $\begin{array}{l}\text { Sichieri R. } \\
\text { et al, 2015. }\end{array}$ & Americas & Brazil & $\begin{array}{l}\text { Cross- } \\
\text { sectional }\end{array}$ & $\begin{array}{l}34,003 * \\
(26,862 \\
\text { adults/ } \\
\text { elderly) }\end{array}$ & $\begin{array}{l}\text { To identify major food } \\
\text { group contributors of } \\
\text { energy intake. }\end{array}$ & $>10$ & 9 (high) & $\begin{array}{l}\text { Brazilian } \\
\text { Household } \\
\text { Budget } \\
\text { Survey } \\
(2008-2009)\end{array}$ & $\begin{array}{l}\text { BMI } \\
>25 \mathrm{~kg} / \mathrm{m}^{2} \\
\text { Food } \\
\text { consumption }\end{array}$ & WHO, 1998 & $\begin{array}{l}\text { 2-day Food } \\
\text { Record }\end{array}$ \\
\hline $\begin{array}{l}\text { Sluik D. et } \\
\text { al, 2014. }\end{array}$ & Europe & Netherlands & $\begin{array}{l}\text { Cross- } \\
\text { sectional }\end{array}$ & 2100 & 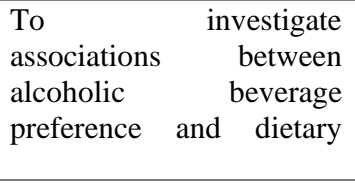 & $19-69$ & 7 (moderate) & DNFCS & $\begin{array}{l}\text { Energy intake } \\
\text { Frequency and } \\
\text { absolute } \\
\text { consumption }\end{array}$ & Mean BMI & $\begin{array}{l}\text { R24h } 2 \text { non- } \\
\text { consecutive } \\
\text { days }\end{array}$ \\
\hline
\end{tabular}


Research, Society and Development, v. 11, n. 2, e27211225434, 2022

(CC BY 4.0) | ISSN 2525-3409 | DOI: http://dx.doi.org/10.33448/rsd-v11i2.25434

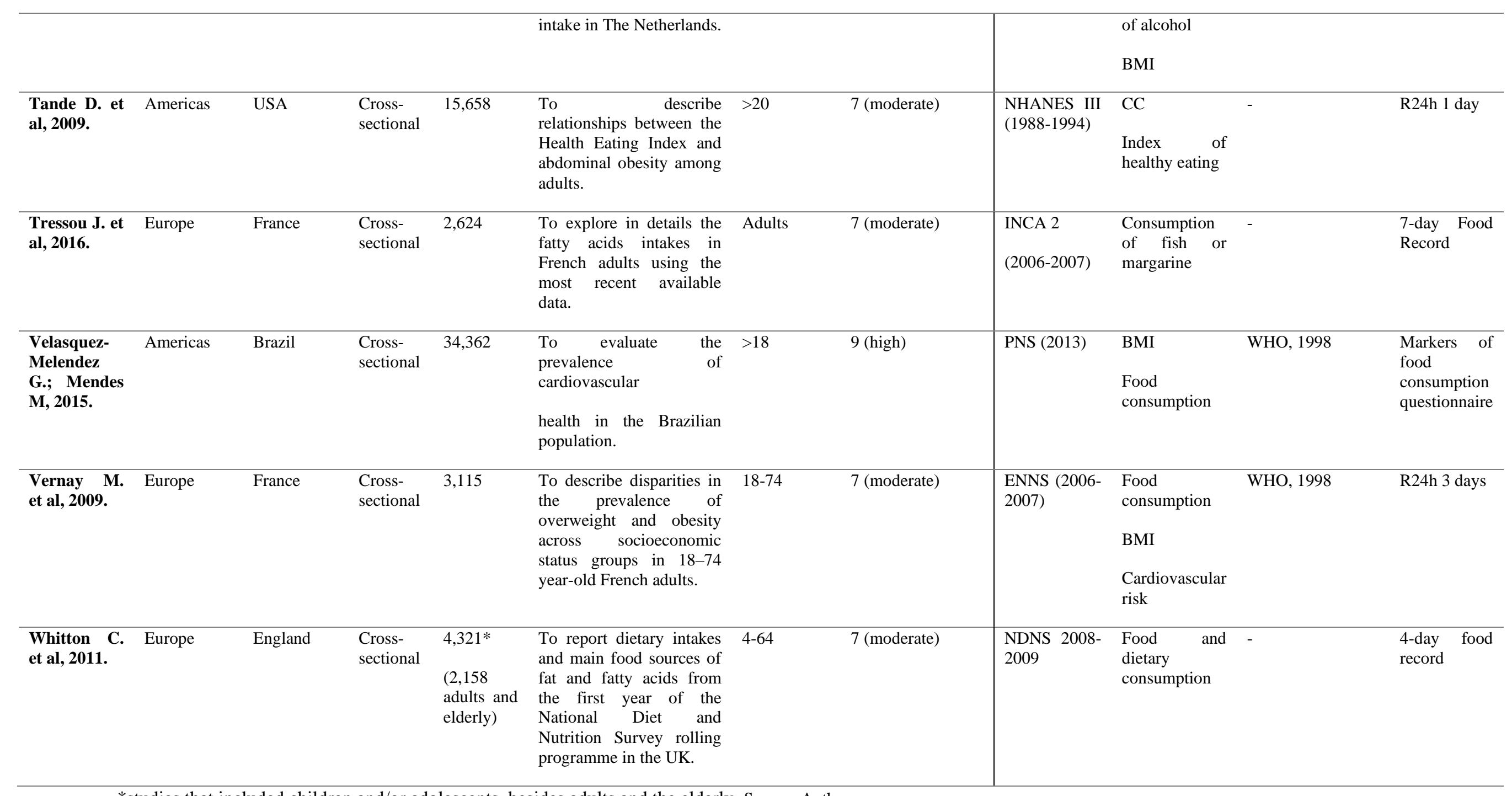

*studies that included children and/or adolescents, besides adults and the elderly. Source: Authors. 
Research, Society and Development, v. 11, n. 2, e27211225434, 2022

(CC BY 4.0) | ISSN 2525-3409 | DOI: http://dx.doi.org/10.33448/rsd-v11i2.25434

\section{Discussion}

Food consumption surveys are used to collect information about the preparation and consumption of food, through observations by skilled personnel (Shim et al., 2014). In the present analysis, the food record was the most frequently used nutritional survey to assess food consumption in large population surveys, followed by the R24H. Some countries have used this type of dietary inquiry, including Brazil (Bezerra \& Sichieri, 2011; Pereira; Duffey; Sichieri, 2014; Sichieri et al., 2015), as well as developed countries such as Spain (Nissensohn et al., 2017; Ruiz et al., 2015, 2016), England (Pot et al., 2015; Pot et al, 2014; Prynne et al., 2009; Whitton et al, 2011), France (Gazan et al., 2016; Tressou et al., 2016), the United Kingdom (Marcenes et al., 2003), and Switzerland (Bjermo et al, 2013).

Although allowing a detailed assessment of food consumption, the food record dispenses with the interviewer and does not feature respondent bias. However, it does present some limitations such as the requirement for literacy and high motivation (Shim et al., 2014). It is possible that preference for its use in European countries is due to the easier application since an interviewer is not necessary. In this sense, it reduces the costs of the research. It should be emphasized that use of this method has greater reproducibility in populations with a high level of education.

Wide variations in the type of equipment used for data collection were observed in these studies, such as the use of tablets, digital cameras, photographic recordings, telephone interviews, and printed forms, which require a certain degree of skill for their use. It is also interesting that most papers that used the food record applied it for four or more days (Bezerra $\&$ Sichieri, 2011; Bjermo et al, 2013; Gazan et al., 2016; Marcenes et al., 2003; Pot et al., 2014; Pot et al., 2015; Prynne et al., 2009; Tressou et al., 2016; Whitton et al, 2011). Accordingly, the choice of this method over a long period of time requires some skills from the interwire, such as: good collaborative ability, motivation, and an understanding of the importance of the study. These avoid possible biases resulting from delay in the implementation of the method, such as underreporting or overestimation, as well as withdrawal of the interviewer (FAO, 2018).

The R24h also provides details of food intake and offers greater convenience to the respondent than food record. However, there is a possibility of both respondent and interviewer bias, and the method requires trained interviewers. In this review, only four articles described the training of the interviewers (Barr et al., 2016; Bell et al., 2015; Beltrán-de-Miguel et al., 2015; Kant; Graubard, 2015). As all the papers were based on national surveys, generally using secondary data from databases, it is assumed there was a lack of information on interviewer training. Furthermore, the information was not available in the database, but was described in the survey methodology.

Both the food record and the R24h require multiple days of evaluation to estimate habitual intake (Shim et al., 2014). Recording of several days of consumption when using short-term records, such as the R24h and the food record, is necessary to remove intrapersonal variability, reducing the random error inherent in usual food consumption (Morimoto et al, 2011).

In relation to anthropometric measurements, most of the studies used the BMI as an indicator to assess anthropometric nutritional status. The evaluation of body composition may be relevant as it evaluates the role of body components to health, as well as its relations with the emergence of NCDs. There are various methods for the assessment of body composition that are considered accurate and sophisticated, such as hydrostatic weighing and dual-energy x-ray absorptiometry (DEXA). However, their use in epidemiological studies is impractical because of the high cost. Therefore, BMI and waist circumference are widely used for anthropometric indicators in population studies due to their practicality and low cost (Rezende et al, 2007) .

In practice, the anthropometric data are compared for the interpretation of anthropometric nutritional status to reference values, which were obtained from specific populations (De Onis, 1996). Thus, it is necessary to consider different cut-off points for the interpretation of distinct life cycles, such as aging. 
Research, Society and Development, v. 11, n. 2, e27211225434, 2022

(CC BY 4.0) | ISSN 2525-3409 | DOI: http://dx.doi.org/10.33448/rsd-v11i2.25434

The WHO (WHO, 2002) defines an aged or 'older person' as a 60 years old individual or older. This definition, according to the WHO, is appropriate for developing countries; however, in some contexts, especially in developed countries, considering the significant increase in life expectancy in recent years, the classification of 65 years or more for an elderly person may be more appropriate.

However, it's considering that chronological age is not necessarily a precise marker in the monitoring of changes related to aging, because there are important differences related to health, participation, and levels of interdependence among people of the same age. Therefore, it is worth emphasizing that for the purpose of formulating public policies (one of the purposes of national surveys), these variations among older people should be considered (World Health Organization, 2005).

Despite its wide dissemination in epidemiological studies, the use of BMI for assessment of anthropometric nutritional status of the elderly has been questioned, owing to the changes in body composition resulting from the aging process (Cook et al, 2005). Thus, the employment of the same criteria for the classification of BMI in the general adult population and elderly patients is controversial, considering the reduced stature, accumulation of adipose tissue, and reduction of lean body mass and water in the body that occurs in the elderly individual (Silveira, Kac, \& Barbosa, 2009).

The criteria of the WHO ( $<18,5 \mathrm{~kg} / \mathrm{m}^{2}$ - Underweight; 18,5 to $24,9 \mathrm{~kg} / \mathrm{m}^{2}$ - Normal weight ; 25,0 to $29,9 \mathrm{~kg} / \mathrm{m}^{2}$ - Preobesity; >30,0 kg/m² - obesity)(World Health Organization, 2000) and those proposed by Lipschitz $\left(<22 \mathrm{~kg} / \mathrm{m}^{2}\right.$ - Underweight; 22,0 to 27,0 - Normal weight; $<27 \mathrm{~kg} / \mathrm{m}^{2}$ - Overweight) (Lipschitz, 1994) et al. are the most commonly used for the assessment of anthropometric nutritional status of the elderly.

In this systematic review, which aimed to evaluate the population studies conducted with adults and elderly patients, it was observed that in the majority of studies, the cut-off points of BMI classification proposed by the WHO for adults were also used for the elderly (Acosta, 2013; Barquera et al., 2009, 2010; Bell et al., 2015; Bezerra \& Sichieri, 2011; Kantet al, 2003; Lei et al., 2016; Marcenes et al., 2003; Pavão, 2013; Sichieri et al., 2015; Velasquez-Melendez et al., 2015; Vernay et al., 2009). However, unlike the cut-off points proposed by Lipschitz et al (Lipschitz, 1994), the WHO classification does not consider the changes in body composition of the elderly. Therefore, it is necessary to critically analyse the classifications of BMI in large population surveys and consider the use of other anthropometric indicators for a complementary diagnosis or update of the criteria proposed by the WHO.

Thirty-five of the 45 papers performed anthropometric measurements. Information on the techniques and protocols used, interviewer training, and replication of anthropometric measures were available in most of these studies or in previous publications. However, in 40.0\% ( $\mathrm{n}=14$ ) (Acosta, 2013; Acosta et al, 2006; Barquera et al., 2009; Barros, 2008; Bell et al., 2015; Bjermo et al, 2013; Lei et al., 2016; Marcenes et al., 2003; Meier et al., 2010; Pavão, 2013; Pisabarro et al., 2009; Pot et al., 2015; Sichieri et al., 2015; Tressou et al., 2016; Vernay et al., 2009), a lack of clarity was observed in the equipment calibration information, which did not appear in previous publications, nor even in official survey sites or documents investigated.

This review contains some limitations that must be considered, such as the possible non-inclusion of all health and nutrition surveys conducted on the continents surveyed, because not all databases were consulted. However, to circumvent this limitation, a manual search was performed to obtain a greater number of studies for inclusion.

It is worth mentioning this study included articles of high methodological quality; thus, the results presented here depict the more common methodologies used and accepted in the scientific community for assessment of food intake and anthropometric nutritional status, allowing, however, their critical analysis, to improve the reproducibility of health and nutrition studies. 


\section{Conclusion}

This review identified the food record and BMI as the most common indicators of the evaluation of food consumption and anthropometry in population surveys conducted with adults and the elderly. The food record and the 24-hour dietary recall were the preferred methods for studies in developed countries, where high education levels and motivation of residents facilitate the application of these methods. BMI, owing to the ease of obtaining its component measurements and the wide application of its use, was the method of choice of the studies that performed anthropometric evaluation. Nevertheless, most of the studies did not use different classifications in the BMI assessment of adults and the elderly, disregarding the specificities of the changes in body composition and the physiological process of aging widely reported in the literature. The lack of clarity or omission in relation to information regarding the quality of dietary or anthropometric surveys, such as interviewer training, calibration of equipment, or replication of anthropometric measurements, were also issues observed in this review that should be reported.

Hence, it should be emphasized that, in population studies that assess health and nutrition, it is important to devise a proper study design, by selecting the method of food survey that best fits the objectives, the use of anthropometric indicators feasible in epidemiology, and the use of cut-off points appropriate for the population studied, with a view toward reducing the biases and providing valid data. Population surveys can thus provide reliable guidance for the formulation of public policies consistent with the epidemiological profile identified in these studies.

\section{Abbreviations}

PROSPERO: International prospective register of systematic reviews

PRISMA: Preferred Reporting Items for Systematic Reviews and Meta-Analyses

NOS: Newcastle-Ottawa quality assessment scale

AHRQ: Agency for Healthcare Research and Quality

BMI: Body Mass Index

NHANES: National Health and Nutrition Examination Survey

ANIBES: Anthropometry, Intake and Energy Balance in Spain

NSH: National Survey of Health and Development

INRAN-SCAL: Italian National Food Consumption Survey

PNDS: National Demography and Health Survey

ENSANUT: Encuesta Nacional de Salud y Nutrición

ENSIN: Encuesta Nacional de Situación Nutricional

INCA 2: Individual and national study on food consumption

NDNS: British National Diet and Nutrition Survey

ORISCAV-LUX: Observation of Cardiovascular Risk Factors in Luxembourg

DNFCS: Dutch National Food Consumption Survey

ENASEM: Estudio Nacional de Salud y Envejecimiento en México

ENIDE: Encuesta Nacional de Ingesta Dietetica

ENSO 2: Segunda Encuesta Nacional de Sobrepeso y Obesidad

NNPAS: National Nutrition and Physical Activity Survey

NEMONIT: German National Nutrition Monitoring 
Research, Society and Development, v. 11, n. 2, e27211225434, 2022

(CC BY 4.0) | ISSN 2525-3409 | DOI: http://dx.doi.org/10.33448/rsd-v11i2.25434

PNS: National Health Research

PDSD: Research Social Dimension of Inequalities

SHIELD: Study to Help Improve Early Evaluation and Management of Risk Factors Leading to Diabetes

FFQ: Food Frequency Questionnaire

R24h: 24-hour dietary recall

WHO: World Health Organization

NCD: Noncommunicable diseases

DEXA: Dual-energy x-ray absorptiometry

\section{References}

Acosta, K. (2013). Socioecomic status and obesity in Colombia La obesidad y su concentración según nivel socioeconómico en Colombia. Revista de Economía Del Rosario., 16(2), 171-200.

Acosta S.J. et al (2005). Estado nutricional de la población cubana adulta. Rev Esp Nutr Comunitaria, 11(1), 18-26.

AHRQ. Agency for Healthcare Research and Quality. (n.d.). Newcastle-Ottawa Quality Assessment Form for Cohort Studies [Internet]. https://www.ncbi.nlm.nih.gov/books/NBK115843/bin/appe-fm3.pdf

Alkerwi, A. et al (2015). Association between nutritional awareness and diet quality: Evidence from the observation of cardiovascular risk factors in Luxembourg (ORISCAV-LUX) study. Nutrients, 7(4), 2823-2838. https://doi.org/10.3390/nu7042823

Alkerwi, A. et al. (2015a). Cross-comparison of diet quality indices for predicting chronic disease risk: findings from the Observation of Cardiovascular Risk Factors in Luxembourg (ORISCAV-LUX) study. 113(2), 259-269. https://doi.org/10.1126/science.aaa1823.

Barquera, S. et al. (2009). Obesity and central adiposity in Mexican adults: results from the Mexican National Health and Nutrition Survey 2006. Salud Publica de Mexico, 51 Suppl 4, S595-603.

Barquera, S. et al. (2010). Hypertension in Mexican adults: results from the National Health and Nutrition Survey 2006. Salud Publica de Mexico, 52 Suppl 1, S63-71. https://doi.org/10.1590/S0036-36342010000700010

Barr, S. I., DiFrancesco, L., \& Fulgoni, V. L. (2016). Association of breakfast consumption with body mass index and prevalence of overweight/obesity in a nationally-representative survey of Canadian adults. Nutrition Journal, 15(33), 2-9. https://doi.org/10.1186/s12937-016-0151-3

Barros, M. B. de A. (2008). Inquéritos domiciliares de saúde: potencialidades e desafios. Revista Brasileira de Epidemiologia, 11(suppl 1), 6-19. https://doi.org/10.1590/S1415-790X2008000500002

Bays, H. E., Chapman, R. H., \& Grandy, S. (2007). The relationship of body mass index to diabetes mellitus, hypertension and dyslipidaemia: Comparison of data from two national surveys. International Journal of Clinical Practice, 61(5), 737-747. https://doi.org/10.1111/j.1742-1241.2007.01336.x

Bell, L. K., Edwards, S., \& Grieger, J. A. (2015). The relationship between dietary patterns and metabolic health in a representative sample of adult Australians. Nutrients, 7(8), 6491-6505. https://doi.org/10.3390/nu7085295

Beltrán-de-Miguel, B., Estévez-Santiago, R., \& Olmedilla-Alonso, B. (2015). Assessment of dietary vitamin A intake (retinol, $\boldsymbol{\alpha}$-carotene, $\boldsymbol{\beta}$-carotene, $\boldsymbol{\beta}$ cryptoxanthin) and its sources in the National Survey of Dietary Intake in Spain (2009-2010). International Journal of Food Sciences and Nutrition, 66(6), 706-712. https://doi.org/10.3109/09637486.2015.1077787

Bezerra, I. N., \& Sichieri, R. (2011). Household food diversity and nutritional status among adults in Brazil. International Journal of Behavioral Nutrition and Physical Activity, 8(22), 1-7. https://doi.org/10.1186/1479-5868-8-22

Bjermo H. et al (2013). Lead, mercury, and cadmium in blood and their relation to diet among Swedish adults. Food and Chemical Toxicology., 57, 161-169.

Cifelli, C. J., et al (2016). Increasing plant based foods or dairy foods differentially affects nutrient intakes: Dietary scenarios using NHANES 2007-2010. Nutrients, 8(7), 1-13. https://doi.org/10.3390/nu8070422

Cook, Z. et al. (2005). Use of BMI in the assessment of undernutrition in older subjects: reflecting on practice. The Proceedings of the Nutrition Society, 64(3), 313-317. https://doi.org/10.1079/PNS2005437

Cooper, R. et al. (2014). Body mass index from age 15 years onwards and muscle mass,strength, and quality in early old age: Findings from the MRC national survey of health and development. Journals of Gerontology - Series A Biological Sciences and Medical Sciences, 69(10), 1253-1259. https://doi.org/10.1093/gerona/glu039

De Onis M, H. J. (1996). Anthropometric reference data for international use: recommendations from a World Health Organization Expert Committee. Am. J. Clin. Nutr., 64, 650-658.

Duarte, A. C. G. (2007). Avaliação nutricional: aspectos clínicos e laboratoriais. São Paulo: Atheneu. 
Research, Society and Development, v. 11, n. 2, e27211225434, 2022

(CC BY 4.0) | ISSN 2525-3409 | DOI: http://dx.doi.org/10.33448/rsd-v11i2.25434

FAO. (2018). Dietary assessment a resource guide to method selection and application in low resource settings. http://www.fao.org/3/i9940en/19940EN.pdf

Ferreira, R. A. B., \& Benicio, M. H. D. (2015). Obesidade em mulheres brasileiras : associação com paridade e nível socioeconômico. Rev Panam Salud Publica, 37(4/5), 337-342. http://www.scielosp.org/pdf/rpsp/v37n4-5/v37n4-5a22.pdf

Fisberg, R. M., Marchioni, D. M. L., \& Colucci, A. C. A. (2009). Avaliação do consumo alimentar e da ingestão de nutrientes na prática clínica. Arquivos Brasileiros de Endocrinologia \& Metabologia, 53(5), 617-624. https://doi.org/10.1590/S0004-27302009000500014

Gazan, R. et al (2016). Drinking Water Intake Is Associated with Higher Diet Quality among French Adults. Nutrients, 8(689), 2-23. https://doi.org/10.3390/nu8110689

Gose, M. et al. (2016). Trends in food consumption and nutrient intake in Germany between 2006 and 2012: results of the German National Nutrition Monitoring (NEMONIT). British Journal of Nutrition, 115(08), 1498-1507. https://doi.org/10.1017/S0007114516000544

Gray-Donald, K., Jacobs-Starkey, L., \& Johnson-Down, L. (2000). Food habits of Canadians: Reduction in fat intake over a generation. Canadian Journal of Public Health, 91(5), 381-385.

Guedes, F. A. G. (2007). Avaliação nutricional de coletividades. (4th ed.). Florianópolis: Editora da UFSC

Guendelman, S. et al (2013). A population-based comparison of weight and weight perceptions among overweight and obese Mexican and Mexican-American men TT - Comparación de base poblacional sobre el peso y percepciones sobre el peso entre hombres mexicanos y mexicano-americano. Salud Publica Mex, 55(supl.4), s451----s458.

Hoffmann, K. et al (2002). Estimating the distribution of usual dietary intake by short-term measurements. European Journal of Clinical Nutrition, 56, S53S62. https://doi.org/10.1038/sj.ejen.1601429

Nacional Cancer Institute (2015). Usual dietary intakes: The NCI method [Internet].

Kant, A K; Graubard, B. (2015). 40-year trends in meal and snack eating behaviors of American adults. 115(5), 213-223. https://doi.org/10.1007/978-162703-673-3

Kordas, K. et al (2012). Being Overweight or Obese Is Associated with Lower Prevalence of Anemia among Colombian Women of Reproductive Age 1 , 2. The Journal of Nutrition, (C), 175-181. https://doi.org/10.3945/jn.112.167767.175

Kruizenga H.M. et al. (2003). Screening of nutritional status in The Netherlands. Clinical Nutrition, 22(2), 147-152. https://doi.org/10.1054/clnu.2002.0611

Leclercq, C. et al. (2009). The Italian National Food Consumption Survey INRAN-SCAI 2005-06: main results in terms of food consumption. Public Health Nutrition, 12(12), 2504-2532. https://doi.org/DOI: 10.1017/S1368980009005035

Lei, L. et al (2016). Dietary intake and food sources of added sugar in the Australian population. British Journal of Nutrition, 115, 868-877. https://doi.org/10.1017/S0007114515005255

Lipschitz, D. (1994). Screening for nutritional status in the elderly. Prim Care, 21, 55-67.

Malta, D. C., Célia, I., \& Szwarcwald, L. (2017). Pesquisas de base populacional e o monitoramento das doenças crônicas não transmissíveis. Inquéritos Apresentação Rev Saude Publica, 51(1), 1S-4S. https://doi.org/10.1590/S1518-8787.201705100supl1ap

Malta, D. C. et al (2008). Inquéritos Nacionais de Saúde: experiência acumulada e proposta para o inquérito de saúde brasileiro. Revista Brasileira de Epidemiologia, 11(supl 1), 159-167. https://doi.org/10.1590/S1415-790X2008000500017

Marcenes, W. et al (2003). The relationship between dental status, food selection, nutrient intake, nutritional status, and body mass index in older people. Cadernos de Saude Publica, 19(3), 809-816. https://doi.org/10.1590/S0102-311X2003000300013

Meier, M. et al (2010). Who eats healthily? A population-based study among young Swiss residents. Public Health Nutrition, 13(12), 2068-2075. https://doi.org/10.1017/S1368980010000947

Melano-Carranza, E., Lasses Ojeda, L. A., \& Ávila-Funes, J. A. (2008). Factores asociados con la hipertensión no tratada en los adultos mayores: resultados del estudio nacional sobre salud y envejecimiento en México, 2001^ies. Rev. Panam. Salud Pública, 23(5), 295-302.

Meller, F.O et al. (2014). Associação entre circunferência da cintura e índice de massa corporal de mulheres brasileiras. Ciência \& Saúde Coletiva, 19(1), 7582. https://doi.org/10.1590/1413-81232014191.2000

Moher, D. et al. (2015). Preferred reporting items for systematic review and meta-analysis protocols (PRISMA-P) 2015 statement. Systematic Reviews, 4(1), 1-9. https://doi.org/10.1186/2046-4053-4-1

Mohr, P. et al. (2007). Personal and lifestyle characteristics predictive of the consumption of fast foods in Australia. Public Health Nutrition, 10(12), 14561463 https://doi.org/10.1017/S1368980007000109

Morimoto, J. M. et al. (2011). Within-person variance for adjusting nutrient distribution in epidemiological studies. Revista de Saúde Pública, 45(3), 621-625. http://www.ncbi.nlm.nih.gov/pubmed/21552760

Nacif, M. (2007). Avaliação antropométrica nos ciclos da vida: uma visão prática. São Paulo: Editora Metha. 
Research, Society and Development, v. 11, n. 2, e27211225434, 2022 (CC BY 4.0) | ISSN 2525-3409 | DOI: http://dx.doi.org/10.33448/rsd-v11i2.25434

Nissensohn, M. et al. (2017). Beverage consumption habits among the european population: Association with total water and energy intakes. Nutrients, 9(383), 1-13. https://doi.org/10.3390/nu9040383

Nissensohn, M. et al. (2016). Beverage consumption habits and association with total water and energy intakes in the Spanish population: Findings of the ANIBES study. Nutrients, 8(232), 2-18. https://doi.org/10.3390/nu8040232

Pavão, M. R. (2013). Autoavaliação do estado de saúde e a associação com fatores sociodemográficos, hábitos de vida e morbidade na população: um inquérito nacional . Cad Saude Publica, 29(4), 723-734. https://doi.org/10.1590/S0102-311X2013000800010

Pereira RA, Duffey KJ, Sichieri R, P. B. (2014). Sources of excessive saturated fat, trans fat and sugar consumption in Brazil: an analysis of the first Brazilian nationwide individual dietary survey. Public Health Nutr, 17(1), 113-121. https://doi.org/10.1017/S1368980012004892

Pisabarro, R. et al. (2009). Segunda Encuesta Nacional de Sobrepeso y Obesidad ( ENSO 2 ) adultos ( 18-65 años o más ). Revista Medica de Uruguay, 25, 14-26.

Ponce, X. et al (2013). Dietary quality indices vary with sociodemographic variables and anthropometric status among Mexican adults: a cross-sectional study. Results from the 2006 National Health and Nutrition Survey. Public Health Nutrition, 17(08), 1717-1728. https://doi.org/10.1017/S1368980013002462

Pot, G K, et al. (2015). Trends in food consumption over 30 years: evidence from a British birth cohort. European Journal of Clinical Nutrition, 69(7), 817823. https://doi.org/10.1038/ejen.2014.223

Pot, G. K, et al. (2014). Irregular consumption of energy intake in meals is associated with a higher cardio-metabolic risk in adults of a British birth cohort. International Journal of Obesity, 38(12), 1518-1524. https://doi.org/10.1038/ijo.2014.51.

Pot, G. K. et al (2014). Development of the Eating Choices Index (ECI): a four-item index to measure healthiness of diet. Public Health Nutrition, 17(12), 2660-2666. https://doi.org/10.1017/S1368980013003352

Prynne, C. J. et al (2009). Meat consumption after disaggregation of meat dishes in a cohort of British adults in 1989 and 1999 in relation to diet quality. European Journal of Clinical Nutrition, 63(5), 660-666. https://doi.org/10.1038/ejen.2008.7

Rezende, F. et al (2007). Revisão crítica dos métodos disponíveis para avaliar a composição corporal em grandes estudos populacionais e clínicos. ARCHIVOS LATINOAMERICANOS DE NUTRICION, 57(4), 327-334.

Ruiz, E. et al (2016). Macronutrient Distribution and Dietary Sources in the Spanish Population: Findings from the ANIBES Study. Nutrients, 7(6), 47394762. https://doi.org/10.3390/nu7064739

Ruiz, E. et al (2015). Energy intake, profile, and dietary sources in the spanish population: Findings of the ANIBES study. Nutrients, 7, 4739-4762. https://doi.org/10.3390/nu7064739

Sette, S. et al (2018). The third Italian National Food Consumption Survey, INRAN-SCAI Part 1: Nutrient intakes in Italy. Nutrition, Metabolism and Cardiovascular Diseases, 21(12), 922-932. https://doi.org/10.1016/j.numecd.2010.03.001

Shetty, P. S., \& James, W. P. (1994). Body mass index. A measure of chronic energy deficiency in adults. FAO Food and Nutrition Paper, $56,1-57$.

Shi, J., Ying, H., Du, J., \& Shen, B. (2017). Serum Sclerostin Levels in Patients with Ankylosing Spondylitis and Rheumatoid Arthritis: A Systematic Review and Meta-Analysis. BioMed Research International, 2017, 1-7. https://doi.org/10.1155/2017/9295313

Shim, J.-S., Oh, K., \& Kim, H. C. (2014). Dietary assessment methods in epidemiologic studies. Epidemiology and Health, 36, 1-8. https://doi.org/10.4178/epih/e2014009

Sichieri, R. et al. (2015). Major food sources contributing to energy intake - a nationwide survey of Brazilians aged 10 years and older. British Journal of Nutrition, 113(10), 1638-1642. https://doi.org/10.1017/S0007114515001075

Silva, D. F. de O., Lyra, C. de O., \& Lima, S. C. V. C. (2016). Padrões alimentares de adolescentes e associação com fatores de risco cardiovascular: uma revisão sistemática. Ciência \& Saúde Coletiva, 21(4), 1181-1196. https://doi.org/10.1590/1413-81232015214.08742015

Silveira, E. A., Kac, G., \& Barbosa, L. S. (2009). Prevalência e fatores associados à obesidade em idosos residentes em Pelotas, Rio Grande do Sul, Brasil: classificação da obesidade segundo dois pontos de corte do índice de massa corporal. Cad Saude Publica, 25(7), 1569-1577. https://doi.org/10.1590/S0102311 X2009000700015

Sluik, D., Engelen, A. I., \& Feskens, E. J. (2014). Fructose consumption in the Netherlands: the Dutch national food consumption survey 2007-2010. European Journal Of Clinical Nutrition, 69, 475

Sluik, D. et al. (2014). Alcoholic beverage preference and diet in a representative Dutch population: the Dutch national food consumption survey 2007-2010. European Journal Of Clinical Nutrition, 68, 287.

Sperandio, N., \& Priore, S. E. (2017). Inquéritos antropométricos e alimentares na população brasileira: importante fonte de dados para o desenvolvimento de pesquisas. Ciência \& Saúde Coletiva, 22(2), 499-508. https://doi.org/10.1590/1413-81232017222.07292016

Szwarcwald, C. L. et al (2014). Pesquisa Nacional de Saúde no Brasil: concepção e metodologia de aplicação. Ciência \& Saúde Coletiva, 19, 333-342. https://doi.org/10.1590/1413-81232014192.14072012

Tande, D. L., Magel, R., \& Strand, B. N. (2009). Healthy Eating Index and abdominal obesity. Public Health Nutrition, 13(02), 208-214. https://doi.org/10.1017/S1368980009990723 
Research, Society and Development, v. 11, n. 2, e27211225434, 2022

(CC BY 4.0) | ISSN 2525-3409 | DOI: http://dx.doi.org/10.33448/rsd-v11i2.25434

Tressou, J. et al (2016). Fatty acid dietary intake in the general French population: are the French Agency for Food, Environmental and Occupational Health \&amp; Safety (ANSES) national recommendations met? British Journal of Nutrition, 116(11), 1966-1973. https://doi.org/10.1017/S000711451600413X

Velasquez-Melendez, G. et al (2015). Prevalência de saúde cardiovascular ideal na população brasileira - Pesquisa Nacional de Saúde (2013). Revista Brasileira de Epidemiologia, 18(2013), 97-108. https://doi.org/10.1590/1980-5497201500060009

Vernay, M. et al. (2009). Association of socioeconomic status with overall overweight and central obesity in men and women: the French Nutrition and Health Survey 2006. BMC Public Health, 9, 215. https://doi.org/10.1186/1471-2458-9-215

Viacava, F. (2002). Redalyc Informações em saúde : a importância dos inquéritos populacionais Health information : the relevance of health surveys. 7(4), $607-621$

Whitton C. et al. (2011). National Diet and Nutrition Survey: fat and fatty acid intake from the first year of the rolling programme and comparison with previous surveys. In British Journal of Nutrition (Vol. 106). https://doi.org/10.1017/S0007114511002911

WHO. (2002). Active Ageing: A Policy Framework. The Aging Male, 5(1), 1-37. https://doi.org/10.1080/713604647

Willet, W. (2013). Nutritional Epidemiology (3nd ed.). New York: Oxford University Press.

World Health Organization. (2000). Obesity: Preventing and managing the global epidemic. Report of a WHO consultation. WHO Technical Report Series 894. World Health Organization Technical Report Series, 894, 1-253. http://www.ncbi.nlm.nih.gov/pubmed/11234459

World Health Organization. (2005). Envelhecimento Ativo: Uma política de saúde. Organização Pan Americana de Saúde, 1-62. https://doi.org/10.1016/S0140-6736(12)61031-9 